Prepared in cooperation with the U.S. Army Corps of Engineers

\title{
Modeling Water Temperature Response to Dam Operations and Water Management in Green Peter and Foster Lakes and the South Santiam River, Oregon
}
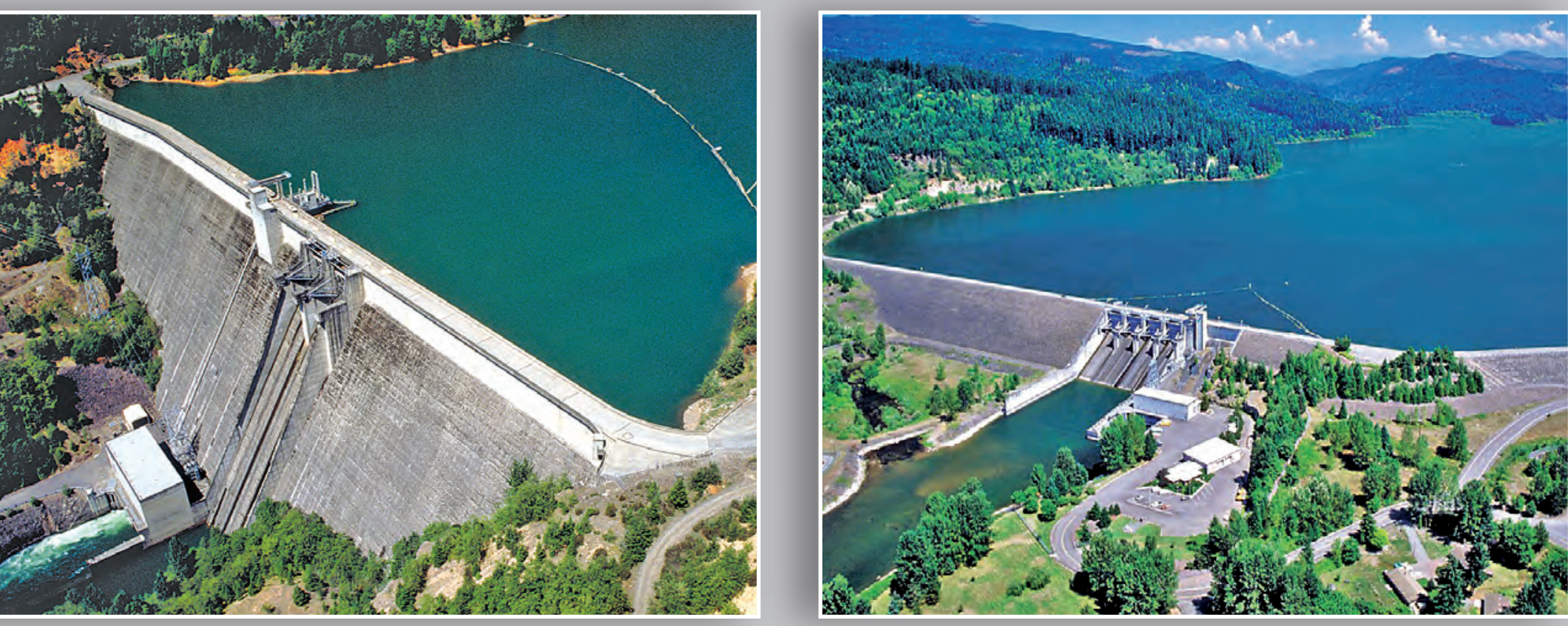

Scientific Investigations Report 2020-5145 
Cover: Green Peter Dam (left) on the Middle Santiam River upstream of Foster Dam (right) on the South Santiam River, Oregon. Photographs taken from the U.S Army Corps of Engineers image gallery (https://www. nwd.usace.army.mil/Media/Images//. 


\section{Modeling Water Temperature Response to Dam Operations and Water Management in Green Peter and Foster Lakes and the South Santiam River, Oregon}

By Annett B. Sullivan and Stewart A. Rounds

Prepared in cooperation with the U.S. Army Corps of Engineers

Scientific Investigations Report 2020-5145 


\section{U.S. Geological Survey, Reston, Virginia: 2021}

For more information on the USGS - the Federal source for science about the Earth, its natural and living resources, natural hazards, and the environment—visit https://www.usgs.gov or call 1-888-ASK-USGS.

For an overview of USGS information products, including maps, imagery, and publications, visit https://store.usgs.gov/.

Any use of trade, firm, or product names is for descriptive purposes only and does not imply endorsement by the U.S. Government.

Although this information product, for the most part, is in the public domain, it also may contain copyrighted materials as noted in the text. Permission to reproduce copyrighted items must be secured from the copyright owner.

Suggested citation:

Sullivan, A.B., and Rounds, S.A., 2021, Modeling water temperature response to dam operations and water management in Green Peter and Foster Lakes and the South Santiam River, Oregon: U.S. Geological Survey Scientific Investigations Report 2020-5145, 27 p., https://doi.org/10.3133/sir20205145.

Data release:

Sullivan, Annett B., 2020, CE-QUAL-W2 water-quality model for Green Peter and Foster Lakes and the South Santiam River, Oregon: 2002-2011: U.S. Geological Survey, https://doi.org/10.5066/P9C1YRV3.

ISSN 2328-0328 (online) 


\section{Contents}

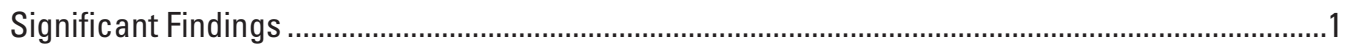

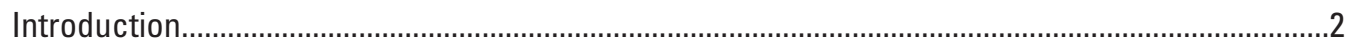

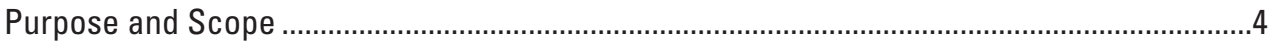

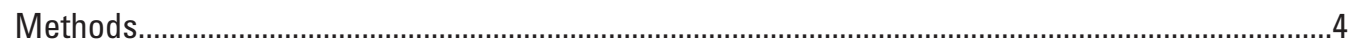

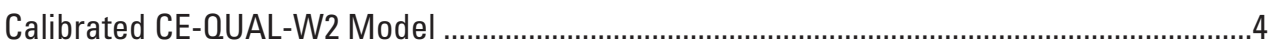

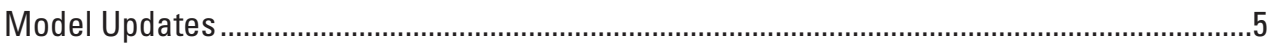

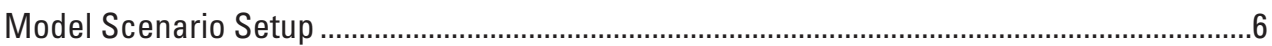

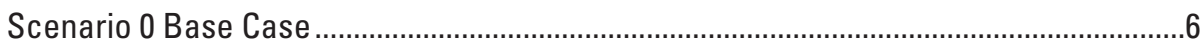

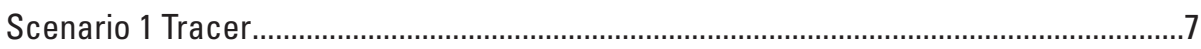

Scenario 2 Block Operations ...........................................................................................

Scenario 3 Foster Lake at Minimum Conservation Pool ......................................................

Scenario 4 “Natural” Seasonal Temperature Target............................................................7

Scenario 5 Natural Step Temperature Target ................................................................. 9

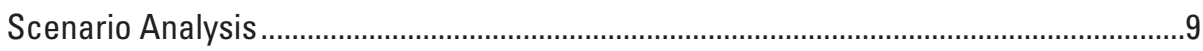

South Santiam River Modeling ..........................................................................................

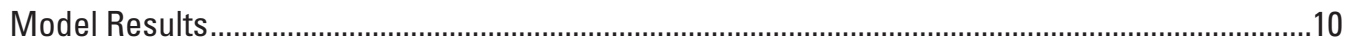

Green Peter and Foster Lake Temperature Scenario Results.................................................10

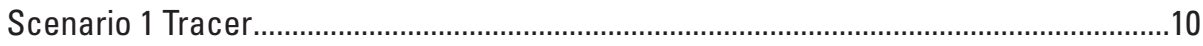

Scenario 2 Block Operations .....................................................................................

Scenario 3 Foster Lake at Minimum Conservation Pool ................................................14

Scenario 4 Natural Seasonal Temperature Target.......................................................14

Scenario 5 Natural Step Temperature Target .............................................................16

Downstream Effects in the South Santiam River ………..................................................18

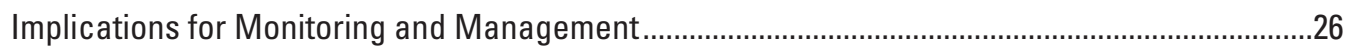

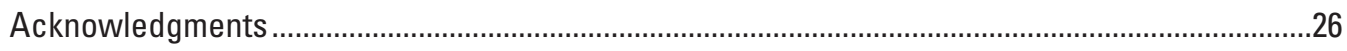

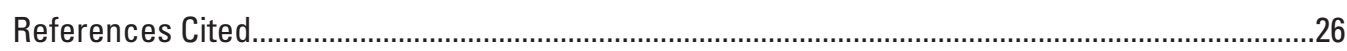

\section{Figures}

1. Map showing study sites in the Santiam River Basin, Oregon ...........................................

2. Graph showing measured water temperature for 2011 for the unregulated South Santiam River downstream of Cascadia, the Middle Santiam River downstream of Green Peter Dam, and the South Santiam River downstream of Foster Dam, Oregon.

3. Graphs showing concentrations of model tracer in Foster Lake representing water sourced from the South Santiam River and water sourced from Green Peter Lake, Oregon, March 5, July 5, and November 24, 2002.

4. Graphs showing concentrations of model tracer in the Foster Dam outflows representing water sourced from the South Santiam River and water sourced from Green Peter Lake, Oregon, modeled years 2002, 2006-08, and 2011.

5. Graphs showing modeled flow and water temperature at the Foster Dam and Green Peter Dam outlets under 10-day block operations, switching the sum of the power and spillway flows between all flow through the power penstock and all flow through the spillway, implemented at Foster Dam and Green Peter Dam, Oregon 
6. Graphs showing modeled Foster Lake, Oregon, water temperature profiles just upstream of the dam and Foster Dam outlet water temperatures for 2002 for the base case and when keeping Foster Lake at its minimum conservation pool.

7. Graphs showing low and water temperature results for 2006-08 from Scenario 4 , which specified a "natural" seasonal temperature target from Buccola for Green Peter Dam releases, and the minimum 40 percent power penstock flow at Green Peter and Foster Dams, Oregon.

8. Graphs showing water temperature results for year 2011 for Scenario 5 for releases from Foster and Green Peter Dams, using a natural step temperature target and various outlet constraints for Green Peter Dam, Oregon...

9. Graphs showing modeled Foster Lake, Oregon, water temperature profiles just upstream of Foster Lake Dam for Scenario 5.

10. Graphs showing modeled daily mean water temperature at 0.1 meter depth in the South Santiam River, Oregon, at selected locations for the base case and Scenario $5 c$ in 2002 .

11. Graphs showing modeled 7-day average of the daily maximum water temperature in the South Santiam River, Oregon, for the base case and for Scenario 5c during May-0ctober 2002.

12. Graphs showing the difference in modeled 7-day daily average of daily maximum water temperature between Scenario $5 c$ and the base case in the South Santiam River, Oregon, 2002.

\section{Tables}

1. Summary of relevant elevations for Foster and Green Peter Dams in the South Santiam River Basin, Oregon.

2. Summary of model scenarios documented in this report

3. Summary of model scenario average flows through the Foster Dam, Oregon, main power penstock, which supplies water to the fish ladder.

4. Summary of model scenario average water temperatures through the Foster Dam, Oregon, main power penstock, which supplies water to the fish ladder.....

5. The dates of Green Peter Dam spillway releases and the corresponding water temperature peak at Foster Dam for Scenario 2, which simulated 10-day block operation at Green Peter Dam, Oregon

6. Summary of the differences between model scenario average water temperatures released through the fish weir and power penstock at Foster Dam, Oregon

7. Summary of the differences between model scenario average water temperatures released through the spillway and power penstock at Foster Dam, Oregon

8. Summary of the differences between model scenario average water temperatures released through the fish hatchery outlet and power penstock at Foster Dam, Oregon 


\section{Conversion Factors}

U.S. customary units to International System of Units

\begin{tabular}{|c|c|c|}
\hline Multiply & By & To obtain \\
\hline \multicolumn{3}{|c|}{ Length } \\
\hline foot $(\mathrm{ft})$ & 0.3048 & meter $(\mathrm{m})$ \\
\hline mile (mi) & 1.609 & kilometer $(\mathrm{km})$ \\
\hline \multicolumn{3}{|c|}{ Area } \\
\hline square foot $\left(\mathrm{ft}^{2}\right)$ & 0.09290 & square meter $\left(\mathrm{m}^{2}\right)$ \\
\hline \multicolumn{3}{|c|}{ Volume } \\
\hline gallon (gal) & 3.785 & liter (L) \\
\hline gallon (gal) & 0.003785 & cubic meter $\left(\mathrm{m}^{3}\right)$ \\
\hline cubic foot $\left(\mathrm{ft}^{3}\right)$ & 0.02832 & cubic meter $\left(\mathrm{m}^{3}\right)$ \\
\hline \multicolumn{3}{|c|}{ Flow rate } \\
\hline foot per second (ft/s) & 0.3048 & meter per second $(\mathrm{m} / \mathrm{s})$ \\
\hline cubic foot per second $\left(\mathrm{ft}^{3} / \mathrm{s}\right)$ & 0.02832 & cubic meter per second $\left(\mathrm{m}^{3} / \mathrm{s}\right)$ \\
\hline \multicolumn{3}{|c|}{ Mass } \\
\hline ounce, avoirdupois (oz) & 28.35 & gram (g) \\
\hline pound, avoirdupois (lb) & 0.4536 & kilogram (kg) \\
\hline
\end{tabular}

International System of Units to U.S. customary units

\begin{tabular}{|c|c|c|}
\hline Multiply & By & To obtain \\
\hline \multicolumn{3}{|c|}{ Length } \\
\hline meter $(\mathrm{m})$ & 3.281 & foot $(\mathrm{ft})$ \\
\hline kilometer (km) & 0.6214 & mile (mi) \\
\hline \multicolumn{3}{|c|}{ Area } \\
\hline square meter $\left(\mathrm{m}^{2}\right)$ & 0.0002471 & acre \\
\hline square meter $\left(\mathrm{m}^{2}\right)$ & 10.76 & square foot $\left(\mathrm{ft}^{2}\right)$ \\
\hline \multicolumn{3}{|c|}{ Volume } \\
\hline liter $(\mathrm{L})$ & 0.2642 & gallon (gal) \\
\hline cubic meter $\left(\mathrm{m}^{3}\right)$ & 264.2 & gallon (gal) \\
\hline cubic meter $\left(\mathrm{m}^{3}\right)$ & 35.31 & cubic foot $\left(\mathrm{ft}^{3}\right)$ \\
\hline \multicolumn{3}{|c|}{ Flow rate } \\
\hline meter per second $(\mathrm{m} / \mathrm{s})$ & 3.281 & foot per second $(\mathrm{ft} / \mathrm{s})$ \\
\hline cubic meter per second $\left(\mathrm{m}^{3} / \mathrm{s}\right)$ & 35.31 & cubic foot per second ( $\left.\mathrm{ft}^{3} / \mathrm{s}\right)$ \\
\hline \multicolumn{3}{|c|}{ Mass } \\
\hline $\operatorname{gram}(\mathrm{g})$ & 0.03527 & ounce, avoirdupois (oz) \\
\hline kilogram (kg) & 2.205 & pound avoirdupois (lb) \\
\hline
\end{tabular}

Temperature in degrees Celsius $\left({ }^{\circ} \mathrm{C}\right)$ may be converted to degrees Fahrenheit $\left({ }^{\circ} \mathrm{F}\right)$ as follows:

$$
{ }^{\circ} \mathrm{F}=\left(1.8 \times{ }^{\circ} \mathrm{C}\right)+32 \text {. }
$$




\section{Datums}

Vertical coordinate information is referenced to the National Geodetic Vertical Datum of 1929 (NGVD29).

Horizontal coordinate information is referenced to the North American Datum of 1983 (NAD 83).

Elevation, as used in this report, refers to distance above the vertical datum.

\section{Abbreviations}

$\begin{array}{ll}\text { CE-QUAL-W2 } & \text { two-dimensional hydrodynamic and water-quality model } \\ \text { FOS } & \text { Foster Lake } \\ \text { GPR } & \text { Green Peter Lake } \\ \text { USACE } & \text { U.S. Army Corps of Engineers } \\ \text { USGS } & \text { U.S. Geological Survey }\end{array}$




\title{
Modeling Water Temperature Response to Dam Operations and Water Management in Green Peter and Foster Lakes and the South Santiam River, Oregon
}

\author{
By Annett B. Sullivan and Stewart A. Rounds
}

\section{Significant Findings}

Green Peter and Foster Dams have altered natural seasonal temperature patterns in the South and Middle Santiam Rivers of the Willamette River Basin in northwestern Oregon. Cold-water releases from Green Peter Dam, upstream of Foster Lake, contribute to the cool-water conditions at Foster Dam. In summer, unseasonably cold water typically is discharged from Foster Dam into the Foster Dam fish ladder, which may be one factor contributing to the low numbers of upstream migrating Chinook salmon (Oncorhynchus tshawytscha) that enter the fish ladder. The U.S. Army Corps of Engineers is leading efforts to improve conditions for Chinook salmon upstream and downstream of these dams by considering structural alterations to Foster Dam and by exploring changes to the way the dams are operated.

The U.S. Geological Survey assisted the U.S. Army Corps of Engineers by using previously calibrated numerical models of flow and water quality for Green Peter and Foster Lakes and for the South Santiam River downstream of Foster Dam. These two-dimensional hydrodynamic and water-quality (CEQUAL-W2) models were used to test scenarios of altered dam operations and alternate water-management strategies. Results of these scenarios provide information and insights into how the mixing and thermal characteristics of the lakes are affected by dam operations, how the mixing and timing of upstream source waters reaching Foster Dam are affected by dam operations, how river and fish-ladder temperature targets might be achieved, and how quickly (or slowly) such changes in the lakes and downstream river reaches occur, relative to typical unmodified operations at Green Peter and Foster Dams.

Significant findings from this study include the following:

- Of the changes in dam operations explored, changes at the upstream Green Peter Dam, as opposed to changes at the downstream Foster Dam, were more effective at altering water temperatures released from Foster Dam. Changes in operations at Green Peter Dam likely were more effective because Green Peter Dam is much taller than Foster Dam and can release large amounts of either warm water (from the surface) or cold water (from deeper in the lake) by opening dam outlets at near-surface or deeper depths during stratified conditions.

- With existing outlets at Green Peter Dam, increased use of the spillway (a near-surface outlet) was most effective at releasing water that mimicked a morenatural seasonal temperature pattern in summer. Use of the spillway would allow dam operators to access and release warmer surface waters from the stratified lake in summer.

- The temperature of water released from Green Peter Dam changed as the water traveled into and through Foster Lake as a result of mixing with water from other sources to Foster Lake (such as the South Santiam River) and as a result of heat exchange with the surrounding environment. Model tracer tests demonstrated that mixing Green Peter Dam releases with water from the South Santiam River was a large factor determining Foster Lake water temperature in spring, late autumn, and winter. In mid-summer, Green Peter Dam releases typically comprised most of the water in Foster Lake.

- Travel time and mixing in Foster Lake caused the effect of alterations at Green Peter Dam to be muted and delayed in their appearance at Foster Dam. For instance, 10-20-day releases of warm surface water at Green Peter Dam peaked at Foster Dam after the spillway releases at Green Peter Dam were halted. Though they have smaller potential effects on water temperature, operational changes at Foster Dam would produce immediate changes to the characteristics of water released from Foster Dam.

- A “fish weir" constructed in 2018 at Foster Dam to facilitate downstream passage of juvenile salmon and adult winter steelhead ( $O$. mykiss) tended to release water with the warmest temperature in summer, with the spillway, power penstock, and an outlet that supplies water to the fish hatchery releasing successively cooler water. The fish weir has a higher release eleva- 
tion than the other outlets and release points and therefore can access the warmest surface waters in Foster Lake. The difference in release temperatures among these outlets, however, was relatively small because the largest elevation difference in these releases are only about 10 meters.

- Downstream of Foster Dam in the South Santiam River, the effects of different dam operations on water temperature decreased with increasing distance downstream, mainly because of increased importance of environmental heat fluxes across the water surface and because of inputs from unregulated tributaries. These factors also increased the daily variability in water temperature in the South Santiam River downstream of Foster Dam. With elapsed time and greater distance downstream of Foster Dam, the South Santiam River becomes less influenced by release temperatures at Foster Dam.

\section{Introduction}

The South Santiam River is a tributary to the Santiam and Willamette Rivers in northwestern Oregon. In 1968, the U.S. Army Corps of Engineers (USACE) completed construction of the Green Peter and Foster Dams in the upstream reaches of the South Santiam River Basin (fig. 1). Together, the two dams and their impounded lakes are used for flood-risk management, hydropower generation, water-quality improvement, irrigation, fish and wildlife habitat, and recreation. Green Peter Dam is 100 meters $(\mathrm{m})$ high $(327 \mathrm{ft})$ and stores $5.28 \times 10^{8} \mathrm{cubic}$ meters $\left(\mathrm{m}^{3}\right)(428,100$ acre-ft) of water at a full pool elevation of $309.4 \mathrm{~m}$ (1,015 ft). Green Peter Lake receives inflow from Quartzville Creek, the Middle Santiam River, and several smaller tributaries. Foster Dam is located about $13 \mathrm{~km}(8 \mathrm{mi})$ downstream of Green Peter Dam and regulates and smooths flow from power peaking operations at Green Peter Dam before discharging water to the South Santiam River. Foster Dam is $38 \mathrm{~m}$ (126 ft) high and stores $7.49 \times 10^{7} \mathrm{~m}^{3}(60,700$ acre- $\mathrm{ft})$ of water at a full pool elevation of $195.4 \mathrm{~m}(641 \mathrm{ft})$. In addition to the inflow from Green Peter Dam, Foster Lake also receives flow from the unregulated South Santiam River and several smaller tributaries.

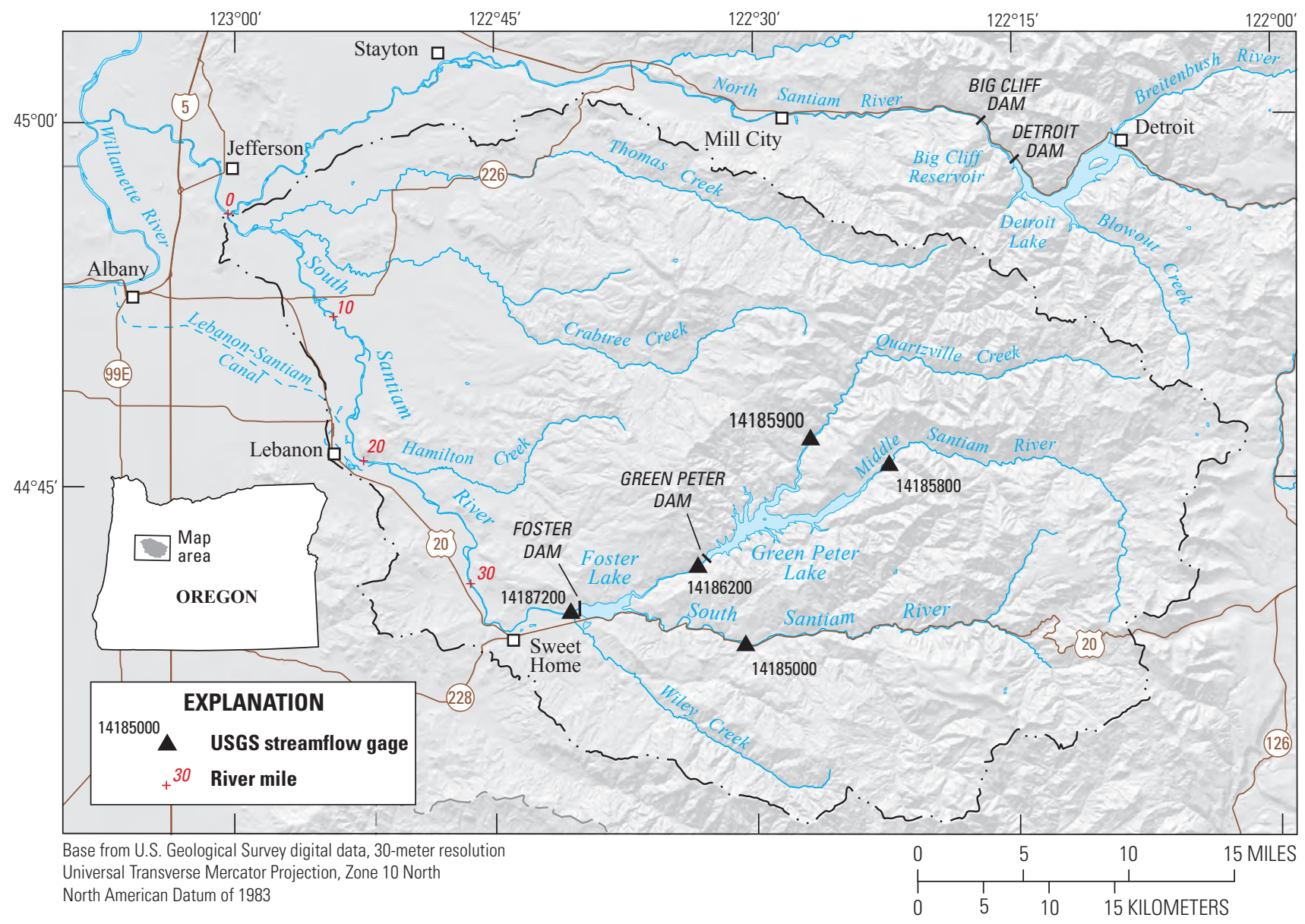

Figure 1. Study sites in the South Santiam River Basin, Oregon. Reproduced from Buccola and others, 2017. 
In spring and summer, the near-surface waters of Green Peter and Foster Lakes warm as the lakes are exposed to increasing amounts of solar radiation and the typically warm and dry weather conditions of summer in western Oregon. Because warm water generally is less dense than cold water, these lakes (especially Green Peter Lake because of its greater depth) develop a distinct vertical thermal profile, with a layer of wind-mixed warmer water floating on top of deeper water that remains cool and somewhat isolated from the atmosphere (Fischer and others, 1979). As a result of this "vertical thermal stratification," dam outlet structures at different depths in the lake will release water with distinctly different temperatures during summer and autumn when the lake is stratified. Deep outlets may release unseasonably cold water during summer, whereas surface outlets will release warmer water. At Green Peter Dam, several outlets are available to release water, but hydropower is generated from water sourced from an outlet structure that is deep enough in the lake to release unseasonably cold water during summer.

Like many large dams, Green Peter and Foster Dams and their summer-stratified reservoirs have altered the natural seasonal temperature pattern in rivers immediately downstream. The South Santiam River is cooler in summer and warmer in autumn compared to seasonal patterns in un-regulated river reaches; for example, the South Santiam River upstream of Foster Lake (fig. 2). At the dams, heat from environmental energy fluxes such as solar radiation is stored in the surface layer of the reservoir, whereas cold water nearer the bottom of the reservoir may be released downstream through lowerelevation outlets. In autumn, water levels in the reservoir are decreased in preparation for capturing large inflows from winter storms to minimize the risk of downstream flooding. As a result, lake surface waters warmed during summer are lowered to the elevation of lower outlets and released, further altering the seasonal temperature pattern downstream.

These altered seasonal temperature patterns may affect several life stages of native anadromous fish in the South Santiam River, such as spring Chinook salmon (Oncorhynchus tshawytscha) and winter steelhead (O. mykiss), both of which are listed as threatened under the Endangered Species Act of 1973 (Public Law 93-205, 87 Stat. 884, as amended; E\&S Environmental Chemistry, Inc., and South Santiam Watershed Council, 2000). Adult Chinook salmon return upstream to the South Santiam River in late spring and early summer, with returns peaking in June at Foster Dam. A fish ladder at Foster Dam was constructed to collect returning adult fish for subsequent transportation by truck to locations in the tributaries upstream of the dams. However, the fish ladder has not efficiently attracted fish, and researchers have hypothesized that cool water in the ladder, sourced from Foster Dam's power penstock, is a factor deterring fish from entering the ladder (Keefer and others, 2018).

Computer-based modeling allows reservoir managers to gain insight into proposed modifications to dam outlet structures and altered dam operations before implementing actions in the field. A CE-QUAL-W2 two-dimensional flow and water temperature model of Green Peter and Foster Lakes was developed by West Consultants, Inc. (2005), for 1970-2002. Portions of that model, including the model grid and some model parameters, were used by U.S. Geological

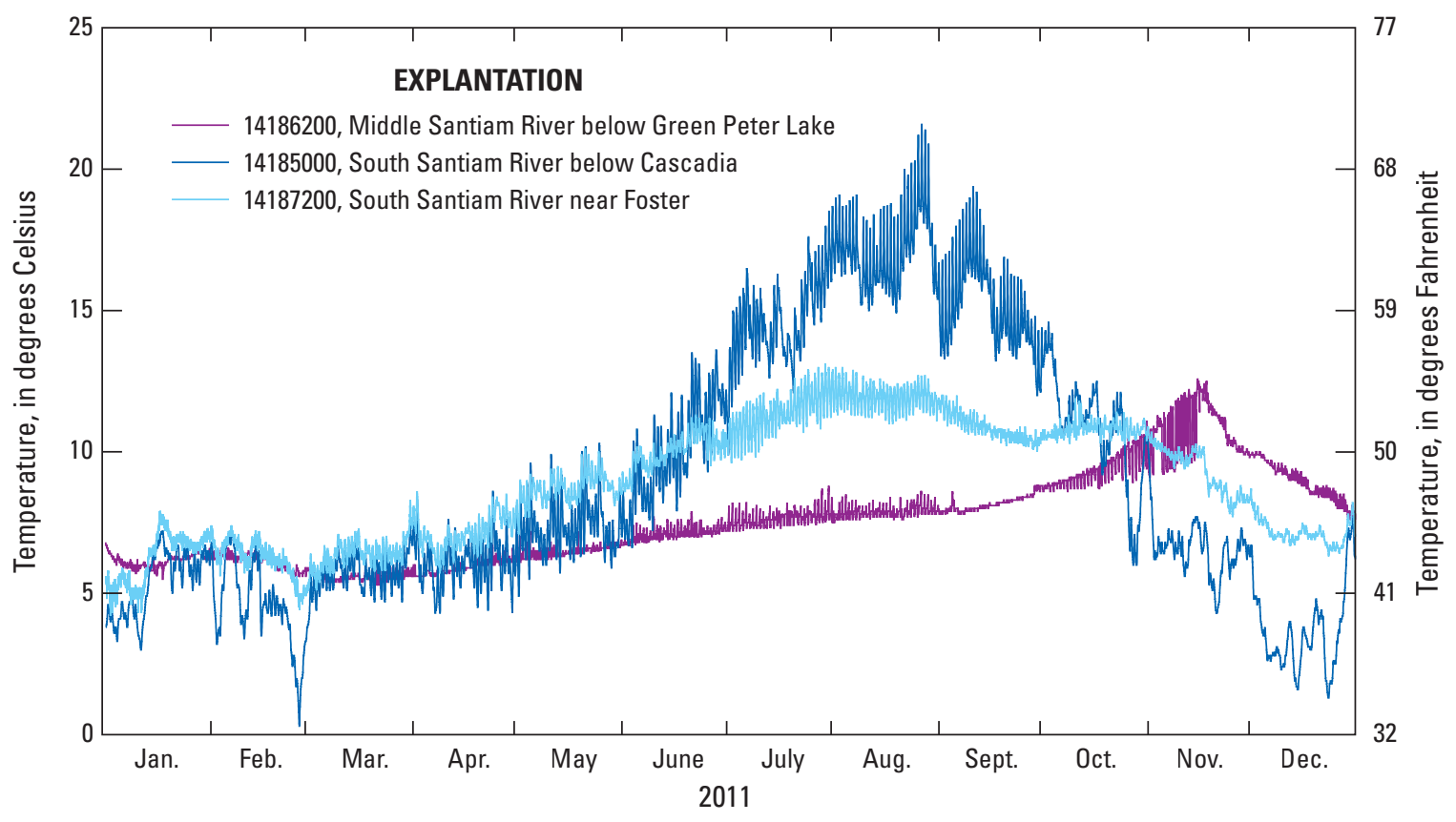

Figure 2. Measured water temperature for 2011 for the unregulated South Santiam River downstream of Cascadia, the Middle Santiam River downstream of Green Peter Dam, and the South Santiam River downstream of Foster Dam, Oregon. 
Survey (USGS) hydrologists in developing an updated Green Peter and Foster Lake model for 2002, 2006, 2008, and 2011 that represented a range of hydrologic and meteorological conditions (Buccola and others, 2013). Similarly, a CE-QUAL-W2 model of the South Santiam River downstream of Foster Dam was developed by the Oregon Department of Environmental Quality and Portland State University for conditions that occurred in 2001 and 2002 (Bloom, 2016). That model was later used by USGS modelers to evaluate the effects of dams and dam operations in other studies (Rounds, 2010).

The USGS model of Green Peter and Foster Lakes was used to run scenarios that examined the effects of possible operational and structural changes at Green Peter and Foster Dams on water temperature (Buccola, 2017). That study demonstrated that releasing warm surface water from Green Peter Lake in summer was effective at producing more-natural seasonal temperatures in the dam releases. The current study extends the efforts of Buccola (2017) to provide additional insights and guidance regarding how operations at Green Peter and Foster Dams affect water temperature in Foster Lake and in the South Santiam River downstream of Foster Dam, and how the dams can be operated to produce more optimum water temperatures to support fish requirements.

\section{Purpose and Scope}

This report documents and describes results of twodimensional (longitudinal and vertical) model simulations of flow, water temperature, and hypothetical nonreactive tracers in Green Peter and Foster Lakes, in the releases from Green Peter and Foster Dams, and in the South Santiam River downstream of Foster Dam. The model results provide guidance to reservoir operators and water-resource professionals who seek to manage the South Santiam River Basin for multiple purposes, including improved conditions for endangered anadromous fish.

Model scenarios were configured to include Green Peter Lake, Green Peter Dam outflows, Foster Lake, Foster Dam outflows, and the South Santiam River downstream of Foster Dam. The scenarios were used to explore mixing and stratification within the lakes and the effects of altering dam-outlet choices and the timing of water releases at the dams, including the incorporation of a temperature target:

- Base case models simulating current operations (Scenario 0);

- The use of hypothetical nonreactive tracers to track the major inputs of water to and through Foster Lake and to the Foster Dam fish ladder under existing operations (Scenario 1);

- Altered operations at Green Peter Dam, in which cold and warm water was released on multi-day schedules, to determine how patterns in release temperatures might translate downstream to temperature patterns in Foster Lake and in Foster Dam releases (Scenario 2);
- Holding the water level of Foster Lake at its minimum conservation pool to determine the effect on water temperature at Foster Dam (Scenario 3);

- Implementation of seasonally variable temperature targets (natural seasonal and natural step targets) for releases from Green Peter Dam to determine the effects on temperatures at Foster Dam (Scenarios 4 and 5); and

- Implementation of the natural seasonal and natural step targets at Green Peter Dam combined with several constraints on the amount of water that could be released over the dam's spillway (Scenarios 4 and $5 \mathrm{c}$ ).

Each scenario was run for 3 model years that included dry, normal, and wet hydrologic conditions; such conditions were drawn from measured conditions that occurred during 2002, 2006 and 2008, and 2011, respectively. In all these hydrologic years, the lakes filled at some point in spring; therefore, severe drought conditions that might cause the lakes not to fill were not included in these analyses.

Particular attention was paid to the use and elevation of outlet structures at Green Peter and Foster Dams so that insights might be gained regarding the use and characteristics of those outlets as they affect the temperature of releases to the fish ladder and downstream.

\section{Methods}

\section{Calibrated CE-QUAL-W2 Model}

CE-QUAL-W2 is a two-dimensional mechanistic flow, temperature, and water quality model used to simulate waterbody conditions from upstream to downstream (longitudinal) and from the water surface to the channel bottom (vertical). The third dimension, from bank to bank (lateral), is well mixed and is not simulated by the model. CE-QUAL-W2 is capable of simulating water level, velocity, flow, temperature, and many aspects of water quality in lakes, reservoirs, rivers, and estuarine systems (Cole and Wells, 2015 and 2017).

The USGS CE-QUAL-W2 model of Green Peter and Foster Lakes was previously configured and calibrated to simulate the hydrologic conditions that occurred in calendar years 2002, 2006 and 2008, and 2011 (Buccola and others, 2013). 2002 was chosen to represent "dry" conditions, and a hybrid model was formed to represent "normal" (2006 prior to October 19 and 2008 after October 19) conditions. Year 2011 was a "wet" hydrologic year.

The model can simulate the temperature of water released from various dam outlets as well as water level, flow, velocity, temperature, stratification, and mixing within the reservoirs. Additionally, the transport and mixing of hypothetical nonreactive tracers can be simulated by the model, tracking from their sources to the points where such tracers exit the model domain. Dam outlets simulated by the original USGS model 
(Buccola and others, 2013) included the existing Foster Dam spillway and power penstock, and the Green Peter Dam power penstock and regulating outlet. Buccola (2017) added the Green Peter Dam spillway to the model for scenario testing. Additional outlets and releases were added to the model as part of this study, as described in the "Model Updates" section of this report.

The South Santiam River model from Foster Dam to its mouth (confluence with the North Santiam River) was developed by the Oregon Department of Environmental Quality and Portland State University for conditions that occurred spring-autumn 2001 and 2002 (Bloom, 2016). That model, within a larger suite of models, was later used by USGS to evaluate point-source thermal loads (Rounds, 2007) and the conditions that might occur in the absence of upstream dams for the Willamette River and several of its major tributaries (Rounds, 2010). USGS continues to use the South Santiam River model as part of other studies to understand thermal conditions and heat transport in the rivers of the Willamette River Basin.

\section{Model Updates}

As part of this study, the existing Green Peter and Foster Lake CE-QUAL-W2 model was updated in several ways:

Model version. The model was updated to use CE-QUAL-W2 version 4.1, based on the code released December 10, 2017 (Cole and Wells, 2017).

Foster Dam fish weir. The new fish weir structure at Foster Dam was added to the model to allow for a moredetailed analysis of its effects. This fish weir was constructed in 2018 at Foster Dam to facilitate downstream passage of juvenile salmon and adult steelhead. Maximum modeled flow through the weir was set to $15 \mathrm{~m}^{3} / \mathrm{s}$ (530 cubic feet per second $\left[\mathrm{ft}^{3} / \mathrm{s}\right]$ ), only for periods when spill was occurring. To maintain a mass balance in the model, the same amount of flow was decreased for water released through the regular spillway.

Foster Dam fish hatchery flow. An outlet was added to the model at Foster Dam to represent outflows to the Foster Dam fish hatchery. This modeled flow only occurred from May 11 to September 3, and flows were set to a constant $1.4 \mathrm{~m}^{3} / \mathrm{s}$ $\left(50 \mathrm{ft}^{3} / \mathrm{s}\right)$ for that time.

Updated and new outlets. The elevation of the main power penstock was updated for all model runs based on information provided by USACE. Also, three new outlets were added to the model at Foster Dam to represent an upper hatchery outlet, an upper penstock, and a lower penstock. These outlets exist but have not been used to release water from Foster Dam. They were added to the model to allow for an estimation of water temperature that could be released from those elevations, if those structures were to be implemented in the future. Flow through these structures was set at $0.001 \mathrm{~m}^{3} / \mathrm{s}$, with the upper hatchery outlet only operating in summer.

This small flow rate would cause the model to withdraw water at the same elevation as the outlet structure. If more water was released through these potential structures, the model algorithms may set withdrawals to be from a wider range of water elevations, so that withdrawal temperatures could be different if stratified temperatures were present in the lake. Additional model runs could examine water temperatures associated with larger flows through these new outlets.

Elevations of the Green Peter and Foster Dam outlets, as modeled in this study, are shown in table 1.

Table 1. Summary of relevant elevations for Foster and Green Peter Dams in the South Santiam River Basin, Oregon.

[Abbreviations: $\mathrm{m}$, meters; $\mathrm{ft}$, feet; NA, not applicable]

\begin{tabular}{llc}
\hline Dam feature & Foster Dam & Green Peter Dam \\
\hline Top of dam & $196.9 \mathrm{~m}(646.0 \mathrm{ft})$ & $310.9 \mathrm{~m}(1,020.0 \mathrm{ft})$ \\
Full pool & $195.4 \mathrm{~m}(641.0 \mathrm{ft})$ & $309.4 \mathrm{~m}(1,015.0 \mathrm{ft})$ \\
Upper Hatchery Outlet ${ }^{1}$ & $192.0 \mathrm{~m}(630.0 \mathrm{ft})$ & $\mathrm{NA}$ \\
Fish Weir & $185.5 \mathrm{~m}(608.6 \mathrm{ft})$ & $\mathrm{NA}$ \\
Upper Power Penstock ${ }^{1}$ & $182.7 \mathrm{~m}(599.3 \mathrm{ft})$ & $295.3 \mathrm{~m}(968.7 \mathrm{ft})$ \\
Spillway Crest & $181.9 \mathrm{~m}(596.8 \mathrm{ft})$ & $246.9 \mathrm{~m}(810.0 \mathrm{ft})$ \\
Power Penstock & $179.8 \mathrm{~m}(590.0 \mathrm{ft})$ & $228.6 \mathrm{~m}(750.0 \mathrm{ft})$ \\
Regulating Outlet & $\mathrm{NA}$ & $\mathrm{NA}$ \\
Lower Power Penstock ${ }^{1}$ & $178.1 \mathrm{~m}(584.3 \mathrm{ft})$ & $\mathrm{NA}$ \\
Lower Hatchery Outlet & $175.6 \mathrm{~m}(576.0 \mathrm{ft})$ & $218.9 \mathrm{~m}(718.2 \mathrm{ft})$ \\
Bottom elevation (model grid) & $162.6 \mathrm{~m}(533.5 \mathrm{ft})$ & \\
\hline
\end{tabular}

1These outlets were not used for current-day operations but were implemented in model scenarios 3-5 to inform possible future operations. 


\section{Model Scenario Setup}

A summary of the model scenarios set up, run, and analyzed as part of this study are shown in table 2. Most models were run for a dry hydrologic year (2002), a normal year (spliced conditions from 2006 and 2008) and a wet year (2011) (table 3), except for Scenario 3, which was only run for 2002. Details about the various scenarios are provided in this section.

\section{Scenario 0 Base Case}

The base case run, Scenario 0, was configured with the actual environmental conditions and reservoir operations from each model year. Construction and calibration of the base case models were documented by Buccola and others (2013), with the model updates as noted above. Results from Scenarios 1-5 were compared to base case results to understand the changes due to modified operations.

Table 2. Summary of model scenarios documented in this report.

["Natural" and "Natural step" are explained in their own sections of this report. Abbreviations: GPR, Green Peter Lake; FOS, Foster Lake; —, not applicable]

\begin{tabular}{|c|c|c|c|c|c|c|}
\hline \multirow{2}{*}{$\begin{array}{l}\text { Scenario } \\
\text { number }\end{array}$} & \multirow[t]{2}{*}{ Scenario name } & \multicolumn{2}{|c|}{$\begin{array}{l}\text { Minimum release through } \\
\text { power penstocks (percentage) }\end{array}$} & \multirow{2}{*}{$\begin{array}{l}\text { GPR } \\
\text { spill }\end{array}$} & \multirow{2}{*}{$\begin{array}{c}\text { Target } \\
\text { temperature } \\
\text { at GPR }\end{array}$} & \multirow[t]{2}{*}{ Notes } \\
\hline & & GPR & FOS & & & \\
\hline 1 & Tracer & - & - & - & - & $\begin{array}{l}\text { Hypothetical tracers to track } \\
\text { sources and mixing }\end{array}$ \\
\hline $2 c$ & FOS_Block3 & - & - & - & - & 3-day block operation at FOS \\
\hline $2 \mathrm{~d}$ & FOS_Block10 & - & - & - & - & 10-day block operation at FOS \\
\hline 3 & Min_Cons_Pool & - & - & - & - & Foster Lake at 613 feet all year \\
\hline 4 & GPR_Spill_60p_nat & 40 & - & Yes & Natural & $\begin{array}{l}\text { "Natural" seasonal temperature } \\
\text { target }\end{array}$ \\
\hline $5 b$ & GPR_Spill & - & - & Yes & Natural step & $\begin{array}{l}\text { Spill allowed; less hydropower } \\
\text { generation }\end{array}$ \\
\hline $5 c$ & GPR_Spill_60p & 40 & - & Yes & Natural step & $\begin{array}{l}\text { Spill limited by baseline } \\
\text { hydropower generation }\end{array}$ \\
\hline $5 d$ & GPR_Floating & - & - & Yes & Natural step & $\begin{array}{l}\text { Spillway as floating outlet, } \\
\text { 1-meter depth }\end{array}$ \\
\hline
\end{tabular}

Table 3. Summary of model scenario average flows through the Foster Dam main power penstock, which supplies water to the fish ladder.

[Yellow shaded cells mean that the flow is less than the 50th percentile value of table data (gray cells). Green shaded cells mean that the flow is greater than that value. All flows are in cubic meter per second.]

\begin{tabular}{cccccccccccccc}
\hline \multirow{2}{*}{ Year } & \multicolumn{2}{c}{ April } & \multicolumn{2}{c}{ May } & \multicolumn{2}{c}{ June } & \multicolumn{2}{c}{ July } & \multicolumn{2}{c}{ August } & \multicolumn{2}{c}{ September } \\
\cline { 2 - 13 } & 1st half & 2nd half & 1st half & 2nd half & 1st half & 2nd half & 1st half & 2nd half & 1st half & 2nd half & 1st half & 2nd half \\
\hline 2002 & 82.9 & 56.7 & 39.6 & 39.3 & 50.8 & 28.6 & 18.3 & 19.6 & 17.0 & 15.4 & 17.8 & 18.7 & 20.7 \\
$2006-08$ & 67.3 & 78.2 & 83.6 & 58.5 & 34.8 & 28.6 & 20.5 & 20.1 & 19.7 & 20.7 & 25.0 & 41.1 \\
2011 & 40.0 & 34.6 & 39.2 & 12.5 & 32.5 & 39.8 & 22.3 & 21.9 & 22.2 & 22.1 & 42.2 & 42.4 \\
\hline
\end{tabular}




\section{Scenario 1 Tracer}

In this scenario, hypothetical nonreactive tracers were used to track the travel and timing of source waters in Foster Lake and to the Foster Dam fish ladder. Use of model tracers are one way to make a model's hydrodynamics and mixing visible (Fischer and others, 1979). Thus, the accuracy of the model tracer is directly related to the strengths and limitations of the model's hydrodynamic approach. For the model used in this study, CE-QUAL-W2, one limitation is that it is two-dimensional, simulating changes vertically and longitudinally, and averaging the processes laterally, from bank-tobank. Though, a two-dimensional model is a good choice for reservoirs that are longer than they are wide and that stratify vertically, such as Green Peter and Foster Lakes; the major hydrodynamic process would be included, while keeping model run-times reasonable.

The model included only three sources of water to Foster Lake, each of which was tagged with one of three tracers: Green Peter, South Santiam River, and Distributed Tributary. The distributed tributary inflows represent unmeasured flows from small tributaries and from any groundwater discharge; such inflows were required to balance the water budget for the Foster Lake model. A fourth tracer, "Initial," was used to tag all water that was in Foster Lake on Day 1 of the model. Tracers in the source waters were set to a concentration of 1.00 (or 100 percent), such that transport, dispersion, and dilution among other source waters would decrease the source tracer concentration and be a true reflection of the percentage of water from that source. As a quality assurance check, the sum of the concentrations of all four sources should, and did, sum to 1.0. These four tracers were tracked within Foster Lake and the Foster Dam outflows, which provided information on how these source waters mix and flow through Foster Lake and to the various outlets at Foster Dam. Discussion of the results from this model scenario focus on the two main tracers of water from Green Peter Dam releases and from South Santiam River inflows.

\section{Scenario 2 Block Operations}

As part of a proposed study to determine the effects of modified water temperatures on fish behavior just downstream of Foster Dam, University of Idaho researchers proposed a set of "block operation" plans, in which the sum of flow releases from Green Peter or Foster Dam power and spillway outlets would be released through only the power penstock or only the spillway at 3- or 10-day intervals (table 2). These scenarios were designed to examine whether temperature cycles (warm or cold, depending on the outlet used) resulting from block operations would translate to meaningful temperature variations at the Foster Dam fish ladder, which was proposed to be paired with fish monitoring to examine fish behavior in and near the ladder at different temperatures. The spillway and power penstock outlets comprised most of the flow released from each dam and flows through other outlets were unchanged. During summer, the temperature of releases from the Green Peter Dam spillway (warm surface water) and power penstock (colder deeper water) would be quite different. The choice of outlet (power penstock or spillway) in the 3- or 10 -day block schedule was determined by a random number generator, which meant that sometimes the same outlet was chosen and used for more than one consecutive 3- or 10-day interval. The field-based study did not go forward, but some of the modeling results are reported here because they are relevant for understanding (1) the magnitude of potential water-temperature changes that might occur as a result of block operations, and (2) the time scales required to transport a change in release temperature at Green Peter Dam downstream to Foster Dam.

\section{Scenario 3 Foster Lake at Minimum Conservation Pool}

In typical years, the Foster Lake water-surface elevation is managed according to its "fill curve," which specifies a seasonal range between $186.8 \mathrm{~m} \mathrm{(612.9ft)}$ and $194.2 \mathrm{~m}(637.1 \mathrm{ft})$. In this scenario, the water surface elevation in Foster Lake was kept at the lowest of those elevations-its minimum conservation pool elevation-during summer when normal operations would call for a higher water level. This elevation was attained in the model by adjusting lake outflows so that they were similar to the sum of all lake inflows. This scenario investigated whether keeping the reservoir water surface elevation lower and closer to the elevation of the outlets would allow the dam to release warm surface waters in summer.

\section{Scenario 4 "Natural" Seasonal Temperature Target}

CE-QUAL-W2 has options that allow the model to seek to meet a downstream temperature target by choosing to release water from outlets at different elevations (Cole and Wells, 2015 and 2017; Rounds and Buccola, 2015). The model's timing and choice of outlets provide useful guidelines for dam operators who may adjust operations to try to provide more ideal conditions for fish. The temperature target used in this scenario was the target developed by Buccola (2017), which represents a more-natural seasonal temperature pattern that occurred prior to construction of Green Peter and Foster Dams (table 4). That temperature target was based on monthly mean water temperatures measured 0.7 mile upstream from the mouth of the Middle Santiam River for 1954 to 1962 (Moore, 1964). Although those data are indicative of historical conditions and pre-dam seasonal patterns, characterizing a truly natural seasonal temperature target for the dam sites is difficult, particularly in the face of changing climatic conditions. Calling this a "natural" seasonal temperature target, therefore, simply means that the temperature target has a more-natural seasonal pattern that is consistent with historical and pre-dam conditions. This option for the model to choose outlets and adjust dam releases 


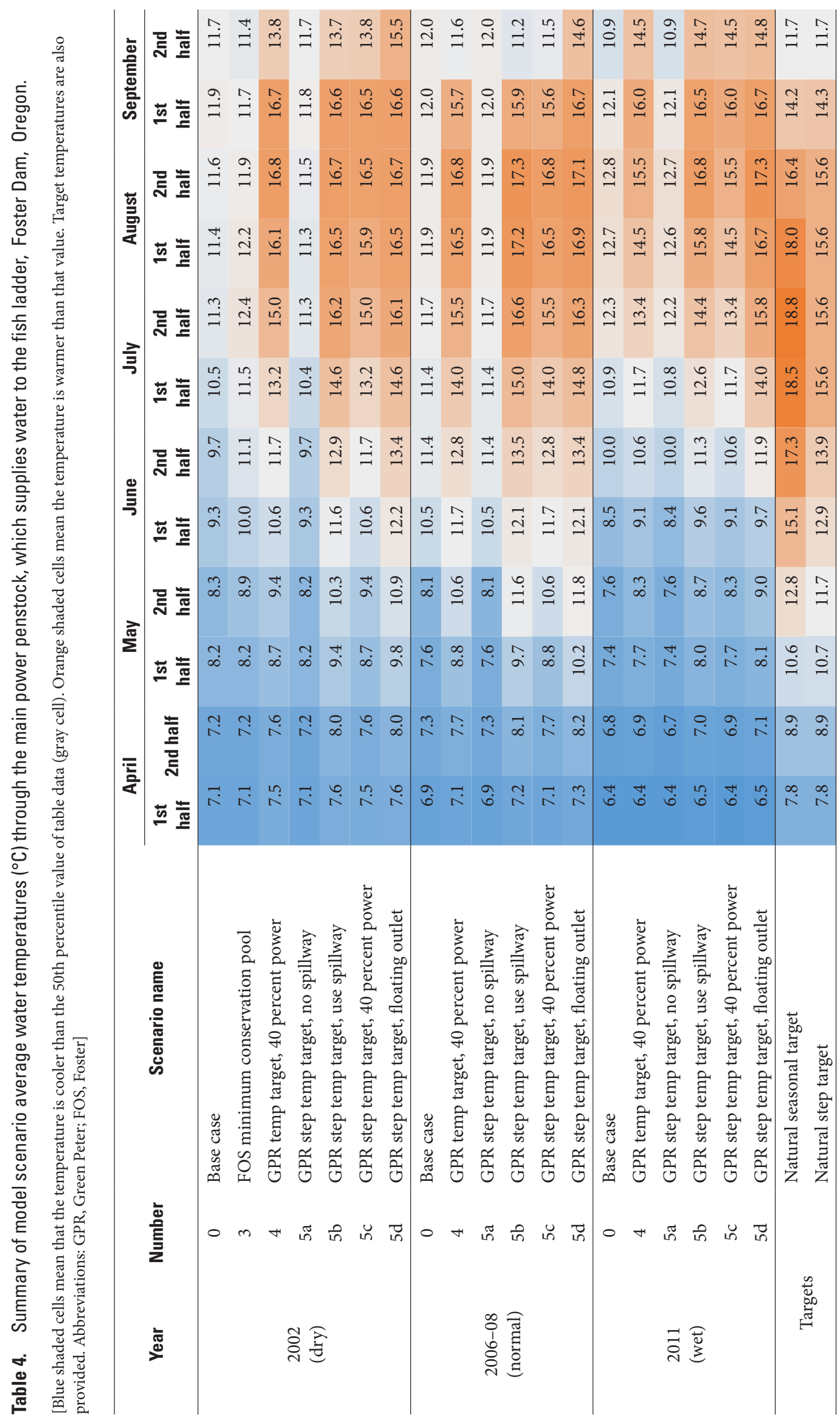


through those outlets to meet a downstream temperature target was only implemented in the model for operations at Green Peter Dam. One constraint in this scenario was imposed that affected the model's ability to meet the downstream temperature target: a minimum of 40 percent of the water released from Green Peter Dam was routed through the power penstock so that a minimum baseline of hydropower could be produced.

\section{Scenario 5 Natural Step Temperature Target}

As an alternative to the more-natural seasonal temperature target developed by Buccola (2017), USACE staff biologists provided summer temperature targets that were based on documented fish preferences. These summer targets took the form of steps at 2-8-week intervals, for the period May 1 through September 15 (table 4). The summer step targets were combined with the natural temperature targets from Buccola (2017) for the rest of the year to create this "natural step" temperature target. This temperature target and the model option to try to meet that target was implemented for operations at Green Peter Dam only. Several alternatives were considered in this scenario, including a scenario with no releases over the spillway (5a), a scenario with spillway releases allowed (5b), a scenario with spillway releases allowed but a minimum flow of 40 percent through the power penstock (5c), and a scenario with the spillway configured as a floating outlet at 1-m depth to allow the model to better access warmer water at the lake surface (5d)(table 2). While a fixed-elevation spillway exists at Green Peter Dam, a floating outlet does not; therefore, implementation of Scenario $5 \mathrm{~d}$ is hypothetical.

\section{Scenario Analysis}

Model results were analyzed to compute several statistics and visualizations, with a focus on water temperature, flow, and tracer concentrations. Locations of interest for water temperature included Foster Lake, releases from the various outlet structures at both dams, as well as the total mixed water temperature downstream of Green Peter and Foster Dams. Mean outlet temperatures were calculated twice a month (first half and second half) for a subset of the scenarios for April through September, along with temperature differences among selected outlets for similar time periods. The thermal structure and tracers within the reservoirs were also analyzed and visualized to better understand mixing, water sources, and thermal stratification in Foster Lake and the effects of the scenarios on those phenomena.

\section{South Santiam River Modeling}

South Santiam River temperatures are important influences on several life stages of sensitive anadromous fish. To examine the effect of possible operations at Green Peter and Foster Dams on South Santiam River water temperatures, results from model scenarios 0 (base case) and $5 c$ (natural step temperature target with a minimum of 40 percent power generation at Green Peter) were input into a model of the South Santiam River, which extends from Foster Dam to the Santiam River. This river modeling downstream of Foster Dam was done to examine the effect of possible operations at Green Peter and Foster Dams on South Santiam River water temperatures, which are important influences on several life stages of sensitive anadromous fish. A CE-QUAL-W2 model of the South Santiam River previously developed by Oregon Department of Environmental Quality and Portland State University (Bloom, 2016) was adapted and run for model year 2002 for these scenarios. South Santiam River models were not yet published or available for use for model years 2006-08 and 2011. 


\section{Model Results}

\section{Green Peter and Foster Lake Temperature Scenario Results}

Although model scenarios were run for three different model years in most cases, the general results and conclusions were similar from the various year types; in such cases, only the results from one year is shown in the charts and graphs. The tables show results from all three year types (dry, normal, and wet).

\section{Scenario 1 Tracer}

Model tracer results illustrated how waters sourced from Green Peter Dam and the unregulated South Santiam River mixed and flowed through Foster Lake and to the various outlets at Foster Dam. The two source waters had differing flow rates through the year and particularly in summer. Flow from the South Santiam River into Foster Lake was strongly seasonal, with higher flows in winter and spring and lower flows in summer. For example, in the years modeled, these flows from November through early June were often higher than $1,000 \mathrm{ft}^{3} / \mathrm{s}$ and during the largest storms were as high as 11,000 $\mathrm{ft} 3 / \mathrm{s}$. In contrast, summer and early autumn flows from July through early October were typically between 30 and $300 \mathrm{ft}^{3} / \mathrm{s}$ in the years modeled.

Green Peter Dam releases to the head of Foster lake also had occasional high flows from late autumn through early June that could be as high as $11,000 \mathrm{ft} 3 / \mathrm{s}$ or more. High-flow releases from Green Peter Dam typically were offset in time from high flows in the Santiam River, however, as the dam was operated to capture high flows during winter storms and then release some of that water after such storms when downstream flows were lower. Summer releases from Green Peter Dam were more constant and typically greater than inflows from the South Santiam River.

Density differences caused by water temperature variations also contributed to flow routing and mixing of source waters in Foster Lake. The South Santiam River had a typically "natural" seasonal temperature pattern for this region, with cold winter and early spring temperatures and a summer maximum above 18 degrees Celsius $\left({ }^{\circ} \mathrm{C}\right.$ ) in August (fig. 2). The temperature of Green Peter Dam releases was cooler than the South Santiam River temperature throughout summer, but with a temperature maximum in late autumn that was warmer than the South Santiam River at that time of year.

The combination of seasonal patterns in flows and water temperature affected how water from Green Peter Dam releases and from the South Santiam River flowed through Foster Lake. During spring storms in 2002 (March 5 in fig. 3), South Santiam River inflows comprised most of the water in Foster Lake and most of the water reaching the outlets of Foster Dam. South Santiam River waters on March 5 were observed not only downstream of the South Santiam confluence, but also mixed into Foster Lake upstream of the confluence. In midsummer 2002 (July 5 in fig. 3), South Santiam River flows were lower, and Green Peter Dam releases made up most of the water in Foster Lake. Those waters released from Green Peter Dam were cold and denser than the warmer water at the surface of Foster Lake, flowing along the reservoir bottom, with warmer South Santiam River water often floating near the surface. In late autumn 2002 (November 24 in fig. 3), the watersurface elevation in Green Peter Lake was drawn down, such that releases from Green Peter Dam were from closer to the lake surface and still retained stored summer heat. That water floated on top of the seasonally cooler South Santiam River water in Foster Lake. Less commonly, the model also showed some periods when South Santiam River waters entered Foster Lake with a temperature and density that caused the inflow to spread into Foster Lake at an intermediate elevation, flowing as a mid-level plume through the lake (not shown in fig. 3).

These source water patterns within Foster Lake had a large effect on the composition of the lake, how water from different sources moved through the lake, and the composition of water exiting the lake through the various outlets at Foster Dam (fig. 4). Green-Peter-Lake-sourced water made up a relatively greater proportion of the total water exiting Foster Dam in July through October in all the years studied. In winter and spring, the water source was more evenly divided between Green Peter Dam releases and water from the South Santiam River. When Foster Lake was stratified in summer, the lake had a vertical separation of source waters that could show up at the Foster Dam outlets because of the elevation differences of the outlets. For instance, the lowest elevation outlet at Foster Dam, the lower hatchery outlet (table 1), had higher proportions of Green Peter tracer in summer in any one model year relative to higher elevation outlets. This was attributable to the cold, dense water released from Green Peter Dam flowing along the bottom of Foster Lake. However, the overall source water differences between the Foster Dam outlets was relatively minor on any one date due to the relative proximity of the outlets vertically.

\section{Scenario 2 Block Operations}

The block operations scenarios, alternating dam releases between spillway and power outlets, demonstrated that these operations at Green Peter Dam were more effective than at Foster Dam in altering outflow temperatures at Foster Dam. An example of this is shown in figure 5, for model year 2002 and a 10-day block operation. Summer block operations at Green Peter Dam increased water temperature of releases at all the in-use Foster Dam outlets, including the weir, spillway, power penstock, and fish hatchery. While increased summer temperatures to the Foster power penstock should be beneficial to spring Chinook Salmon at the Foster fish ladder, the modeled increased temperatures to the hatchery outlet should be considered further to assess how that would affect hatchery fish management. 

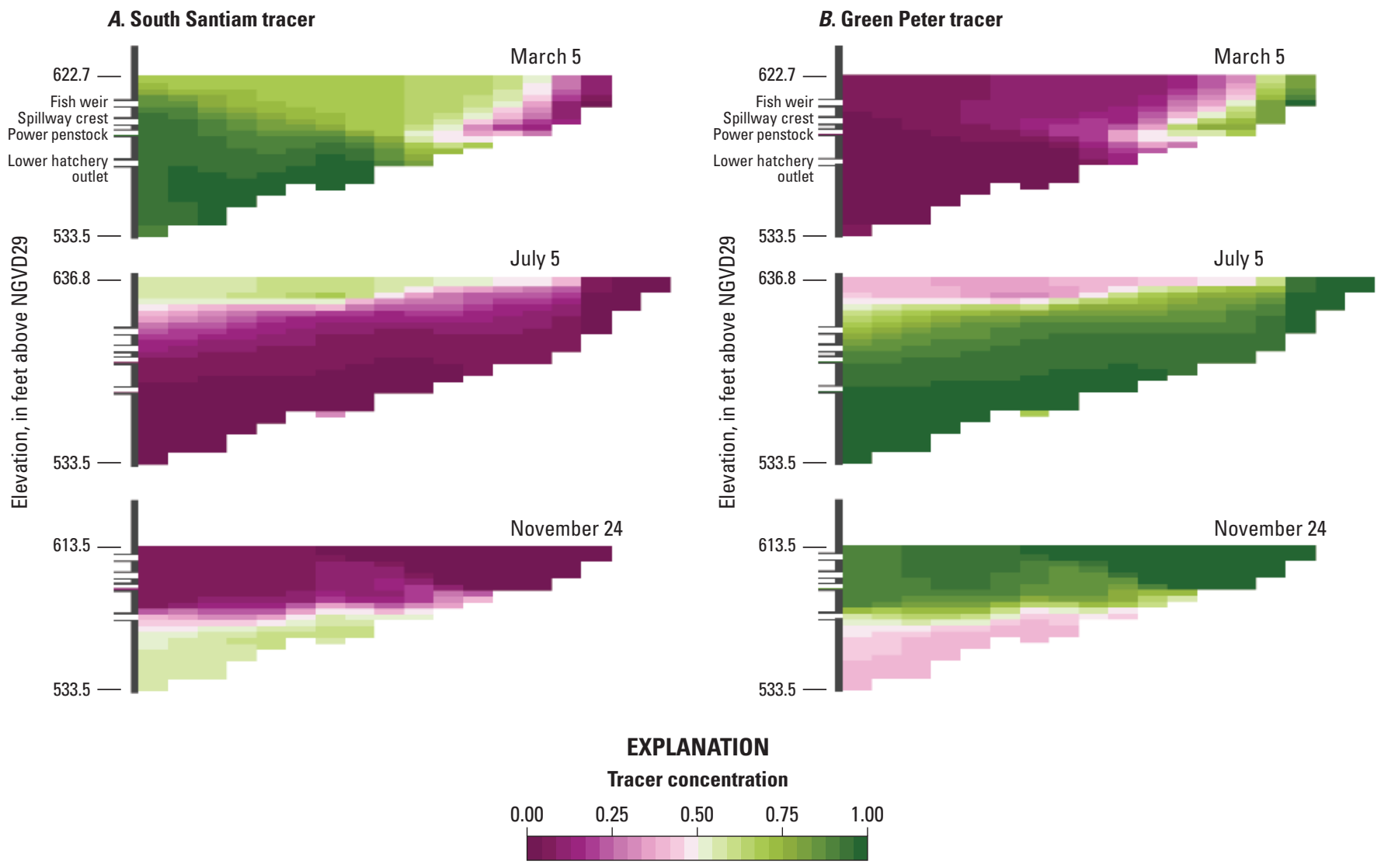

Figure 3. Concentrations of model tracer in Foster Lake representing $(A)$ water sourced from the South Santiam River and $(B)$ water sourced from Green Peter Lake, Oregon, March 5, July 5, and November 24, 2002. NGVD29, National Geodetic Vertical Datum of 1929.

The main factor making block operations at Green Peter Dam more effective was that the temperature difference between waters at the spillway and power penstock were much greater at Green Peter Dam than at Foster Dam. The elevation difference at Green Peter Dam between the spillway and the main power penstock was $48.4 \mathrm{~m}$ (159 ft), while at Foster Dam it was only $2.1 \mathrm{~m}$ (6.8 ft) (table 1$)$. The larger elevation difference, combined with the strong summer temperature stratification in Green Peter Lake (Buccola and others, 2013), resulted in the large temperature differences in outflows from Green Peter Dam during block operations (fig. 5b). Foster Lake is smaller and shallower with less of an elevation difference between the spillway and power penstock, so block operations at Foster Dam did not substantially change the Foster Dam outflow temperatures.

The block operations modeling also demonstrated that Foster Lake buffered and smoothed out distinct variations in the temperature signal from Green Peter Dam releases. The temperature differences in the Green Peter outflow were sharp and distinct. By the time those waters reached Foster Dam, they had been mixed into Foster Lake with South Santiam River inflows. Such mixing, and any additional heat exchanges with the environment as the water moved through Foster Lake, resulted in less sharp temperature differences in the Foster Dam releases. Definite increases in water temperature of Foster Dam releases occurred as a result of block operations that released water over the spillway of Green Peter Dam, but the signals were dampened relative to those nearer to Green Peter Dam.

These scenarios also demonstrated that altered operations at Green Peter Dam required time to appear at Foster Dam (table 5). Release temperatures at Foster Dam did begin to increase shortly after the warm waters were released from Green Peter Dam, but the travel time through Foster Lake muted the effect to some extent and caused the full effect of alterations at Green Peter Dam to be delayed in their appearance at Foster Dam. 

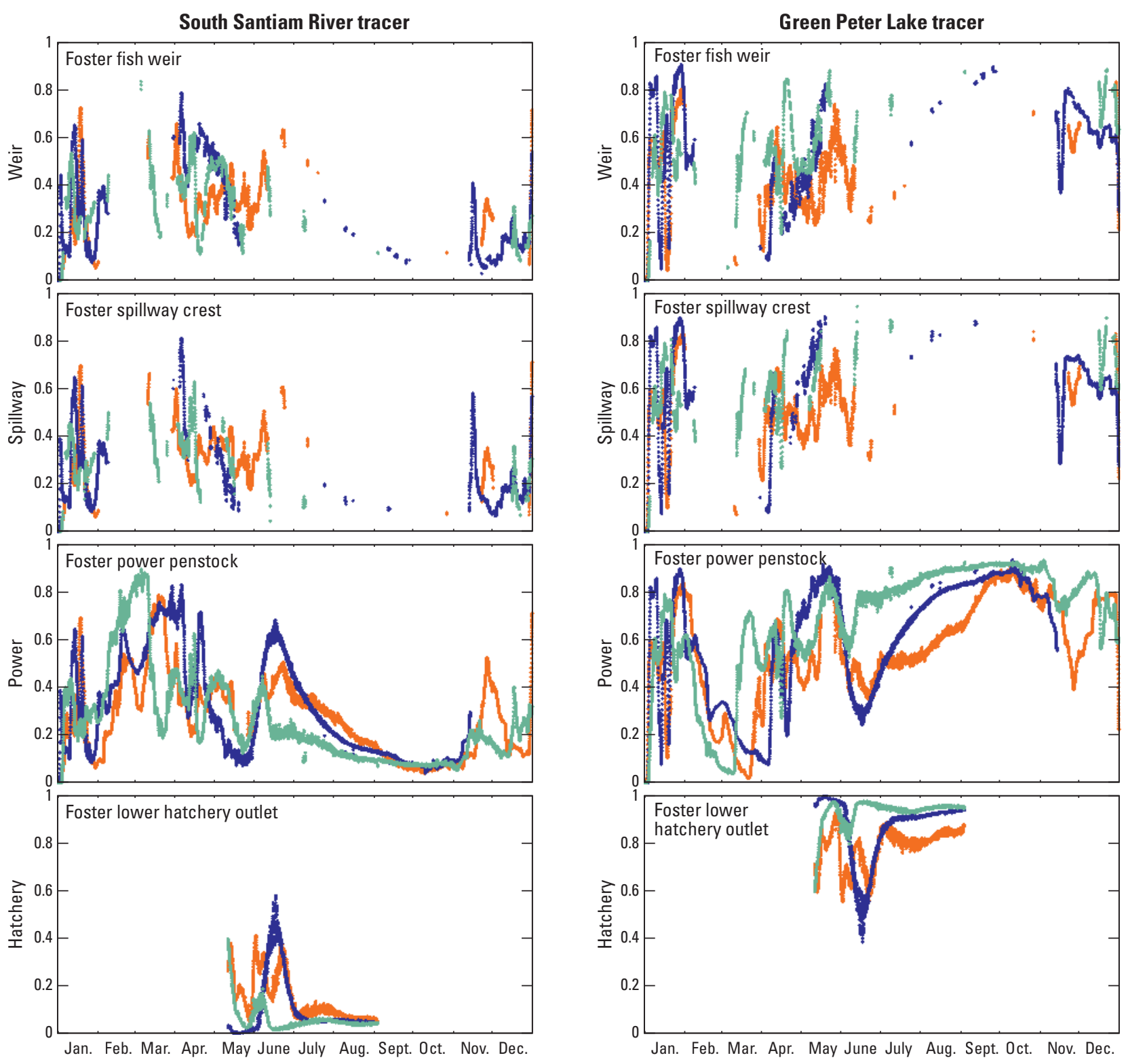

\section{EXPLANATION}

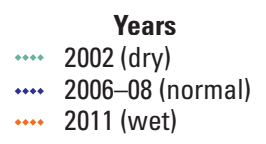

Figure 4. Concentrations of model tracer in the Foster Dam outflows representing water sourced from the South Santiam River (left panels) and water sourced from Green Peter Lake (right panels), Oregon, for modeled years 2002 (dry), $2006-08$ (normal), and 2011 (wet). Year 2006-08 is a hybrid model that combined portions of 2006 and 2008 to achieve hydrologically normal conditions. 
A. 10-day operations at Foster Dam

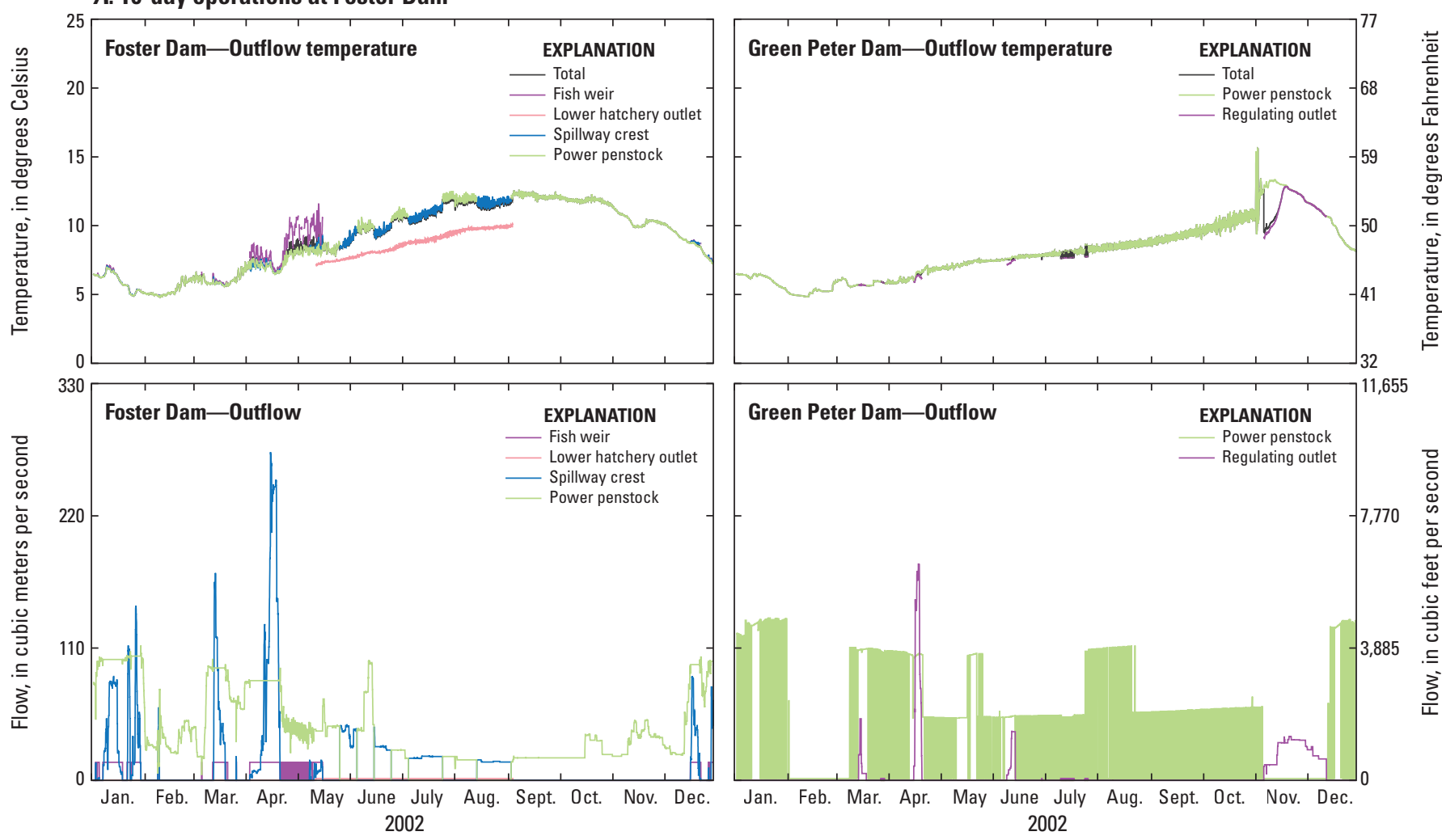

B. 10-day operations at Green Peter Dam
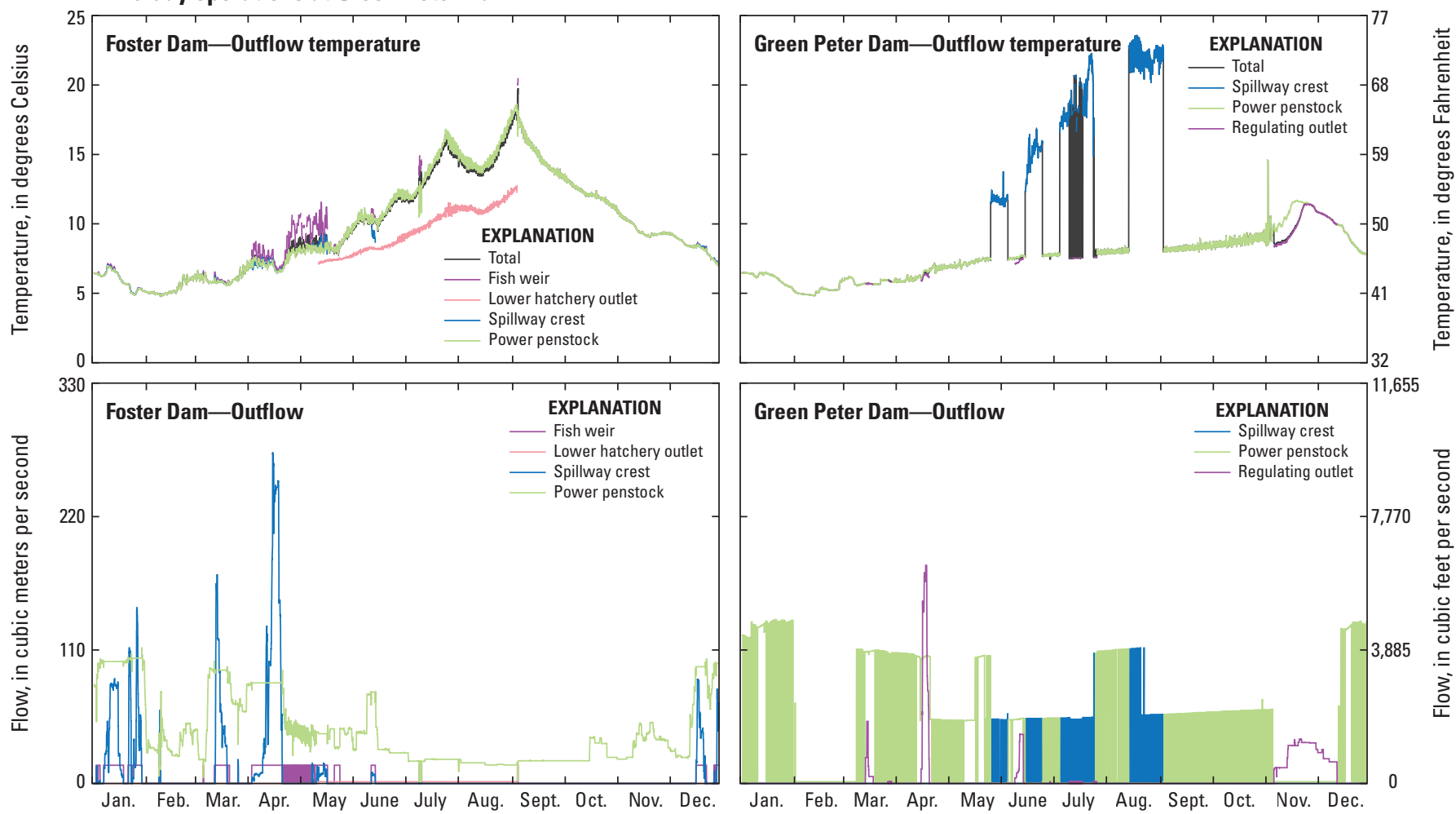

Figure 5. Modeled flow and water temperature at the Foster Dam and Green Peter Dam outlets under 10-day block operations, switching the sum of the power and spillway flows between all flow through the power penstock and all flow through the spillway, implemented at (A) Foster Dam and (B) Green Peter Dam, Oregon. Flow through the regulating outlet was left unchanged. Hatchery flow was $1.4 \mathrm{~m} 3 / \mathrm{s}$ from May 11 to September 3 . 
Table 5. The dates of Green Peter Dam spillway releases and the corresponding water temperature peak at Foster Dam for Scenario 2b, which simulated 10-day block operation at Green Peter Dam, Oregon.

[Abbreviation: NA, no peak observed]

\begin{tabular}{lccc}
\hline \multicolumn{1}{c}{ Green Peter spillway release dates } & \multicolumn{3}{c}{$\begin{array}{c}\text { Foster Dam temperature peak date } \\
\text { (lag time from centroid of Green Peter spill to Foster Dam temperature peak, days) }\end{array}$} \\
\hline \multicolumn{1}{c}{ Year } & $\mathbf{2 0 0 2}$ & $\mathbf{2 0 0 6 - 0 8}$ & NA \\
\hline May 25-June 3 & June 6 (8) & NA & June 24 (6) \\
June 14-June 23 & June 30 (12) & June 27 (9) & July 25 (12) \\
July 4-July 23 & July 24 (11) & July 24 (11) & September 2 (12) \\
August 13-September 1 & September 3 (12) & September 2 (11) & \\
\hline
\end{tabular}

\section{Scenario 3 Foster Lake at Minimum Conservation Pool}

Results from the Foster Lake base case model (Scenario 0) indicated that warm water in the lake during summer typically was located at elevations above the main water outlets (fig. 6A). Thus, the power penstock, which was the source of water to the fish ladder, accessed cooler, mid-level waters. In Scenario 3, the water surface elevation in Foster Lake was kept at the level of its minimum conservation pool all summer, with the idea that a lowered water surface elevation would allow the power penstock to draw from warmer surface waters.

Scenario results showed that water temperatures in the main power penstock, which supplied water to the fish ladder, were not much warmer in this scenario compared to the base case, with an average difference of about $1.5^{\circ} \mathrm{C}$ or less (table 4 ; fig. 6). The difference in water temperature considering all Foster Dam outlet flows as a total was even less. In normal operations (base case), only the upper hatchery outlet would be able to access the warm surface waters of Foster Lake; that outlet was not available in this scenario since the water surface elevation was below it. In Scenario 3, the fish weir and upper power penstock also were able to access warmer surface waters, but they both have limits on flow and the latter was not used for day-to-day operations at this time (table 1).

\section{Natural Seasonal Temperature Target}

Results from scenarios 2 (block operations) and 3 (Foster Lake minimum conservation pool) indicated that operational changes at Green Peter Dam were more effective at producing temperature changes in Foster Dam outflows than operational changes at Foster Dam itself. Similar conclusions were also made by Buccola (2017). Thus, scenarios 4 and 5 focused on operational changes at Green Peter Dam in further detail.

Scenario 4 entailed the use of a more-natural seasonal temperature target for Green Peter outflows and a minimum 40 percent power penstock outflow. With these constraints, the model's selective withdrawal algorithms chose to withdraw additional flow from the warmer surface waters through the spillway until the water surface elevation was drawn down below the spillway elevation, in September (fig. 7). Thereafter, the spillway was no longer an option and the selective withdrawal and outflow-blending algorithms chose to release flow mainly through the power penstocks, which accessed colder water at its lower elevation.

Results from Scenario 4 showed that using the spillway at Green Peter Dam was effective at bringing Green Peter Dam outflow temperatures closer to a more-natural seasonal pattern through the summer until the spillway option was lost. Spillway releases from Green Peter Dam were similar to the temperature target from March through early July for the "normal" model year (2006-08; fig. 7), but mandatory minimum releases of colder water through the power penstocks decreased the combined release temperature. Water temperatures released at Foster Dam also were somewhat closer to the seasonal temperature goal, even without any change in operation at that location, mainly because Green Peter Dam releases comprised most of the water moving through Foster Lake during summer. The average water temperature released from the Foster Dam power penstock, which feeds water to the fish ladder, was as much as $4{ }^{\circ} \mathrm{C}$ warmer during June-July (table 4) when migrating Chinook salmon were near Foster Dam. This temperature increase was largest in the normal (2006-08) and dry (2002) hydrologic model years. 


\section{A. Foster Lake base case (Scenario 0) 2002}
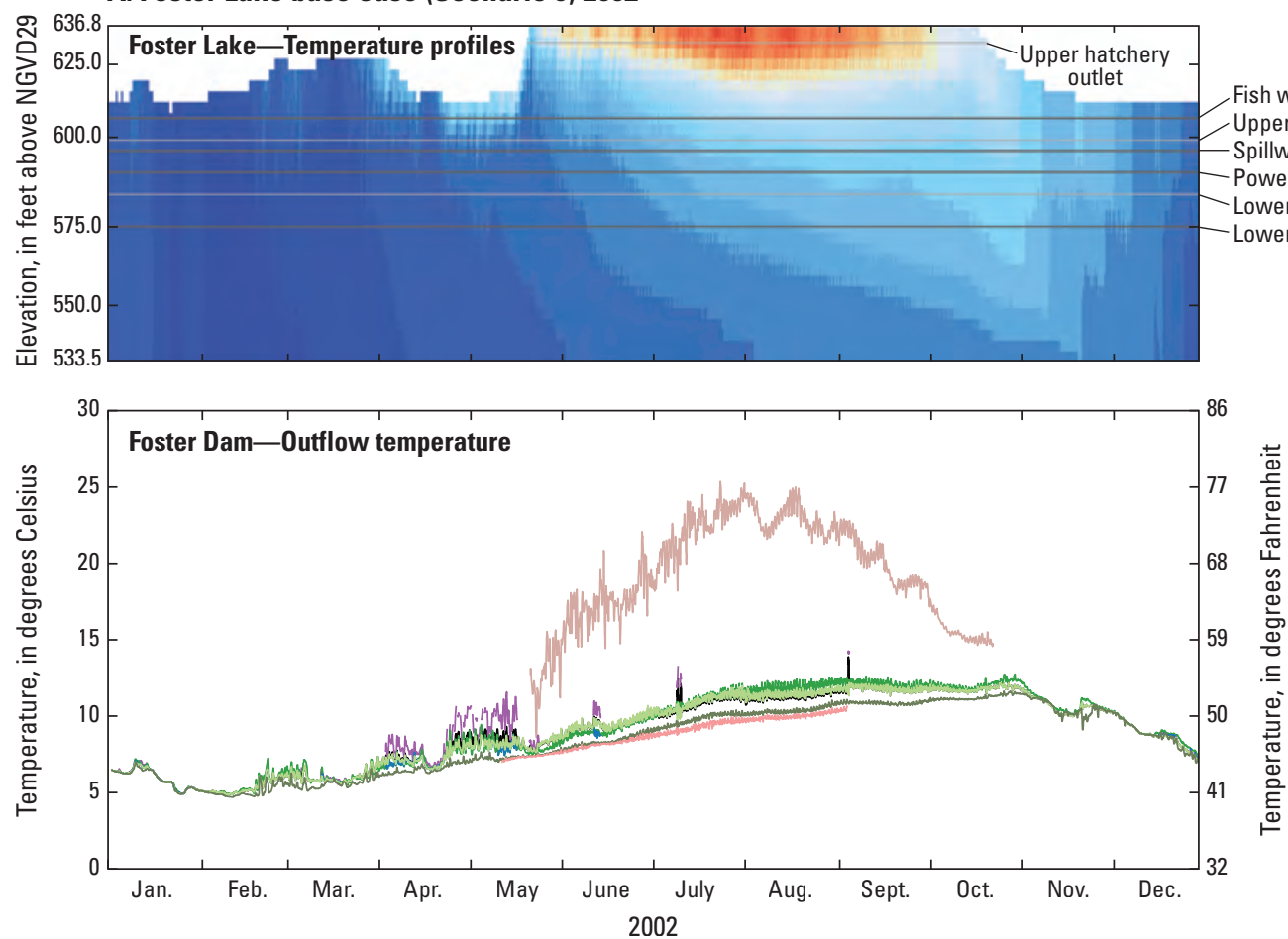

Fish weir

Upper power penstock

- Spillway crest

Power penstock

Lower power penstock

Lower hatchery outlet

\section{EXPLANATION}

Temperature, in degrees Celsius $\begin{array}{lllllll}3 & 7 & 11 & 15 & 19 & 23 & 27\end{array}$

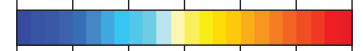

$\begin{array}{lllllll}37 & 45 & 52 & 59 & 66 & 73 & 81\end{array}$ Temperature, in degrees Fahrenheit

- Total

_ Upper hatchery outlet

_ Fish weir

— Upper power penstock

- Spillway crest

Power penstock

— Lower power penstock

- Lower hatchery outlet

\section{B. Foster Lake at minimum conservation pool (Scenario 3) 2002}

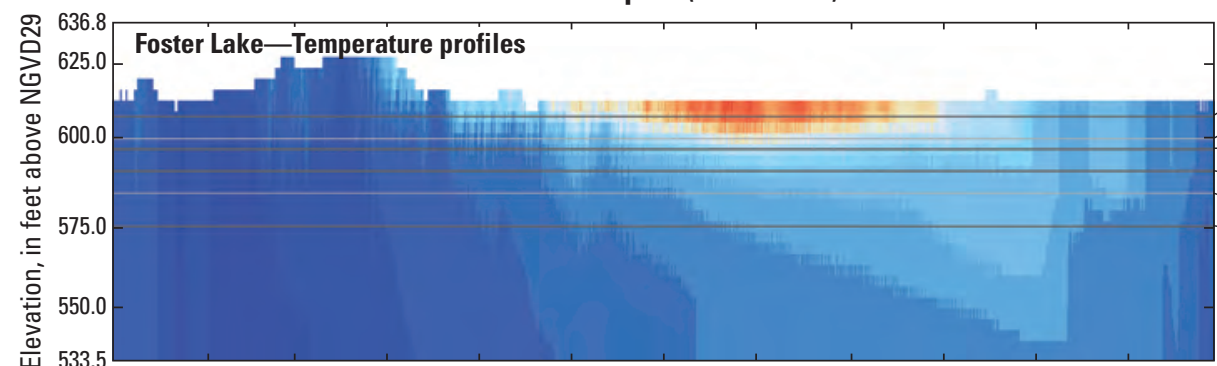

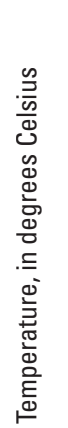

Fish weir

Upper power penstock

- Spillway crest

- Power penstock

Lower power penstock

- Lower hatchery outlet

\section{EXPLANATION}

Temperature, in degrees Celsius $\begin{array}{lllllll}3 & 7 & 11 & 15 & 19 & 23 & 27\end{array}$

$\begin{array}{lllllll}37 & 45 & 52 & 59 & 66 & 73 & 81\end{array}$

Temperature, in degrees Fahrenheit

— Total

- Upper hatchery outlet

_ Fish weir

_ Upper power penstock

— Spillway crest

_ Power penstock

— Lower power penstock

- Lower hatchery outlet

Figure 6. Modeled Foster Lake, Oregon, water temperature profiles just upstream of the dam and Foster Dam outlet water temperatures for 2002 for the base case ( $A$; Scenario 0) and when keeping Foster Lake at its minimum conservation pool ( $B$; Scenario 3). Some dam outlets are not used in typical operations; see table 1 for more information. 

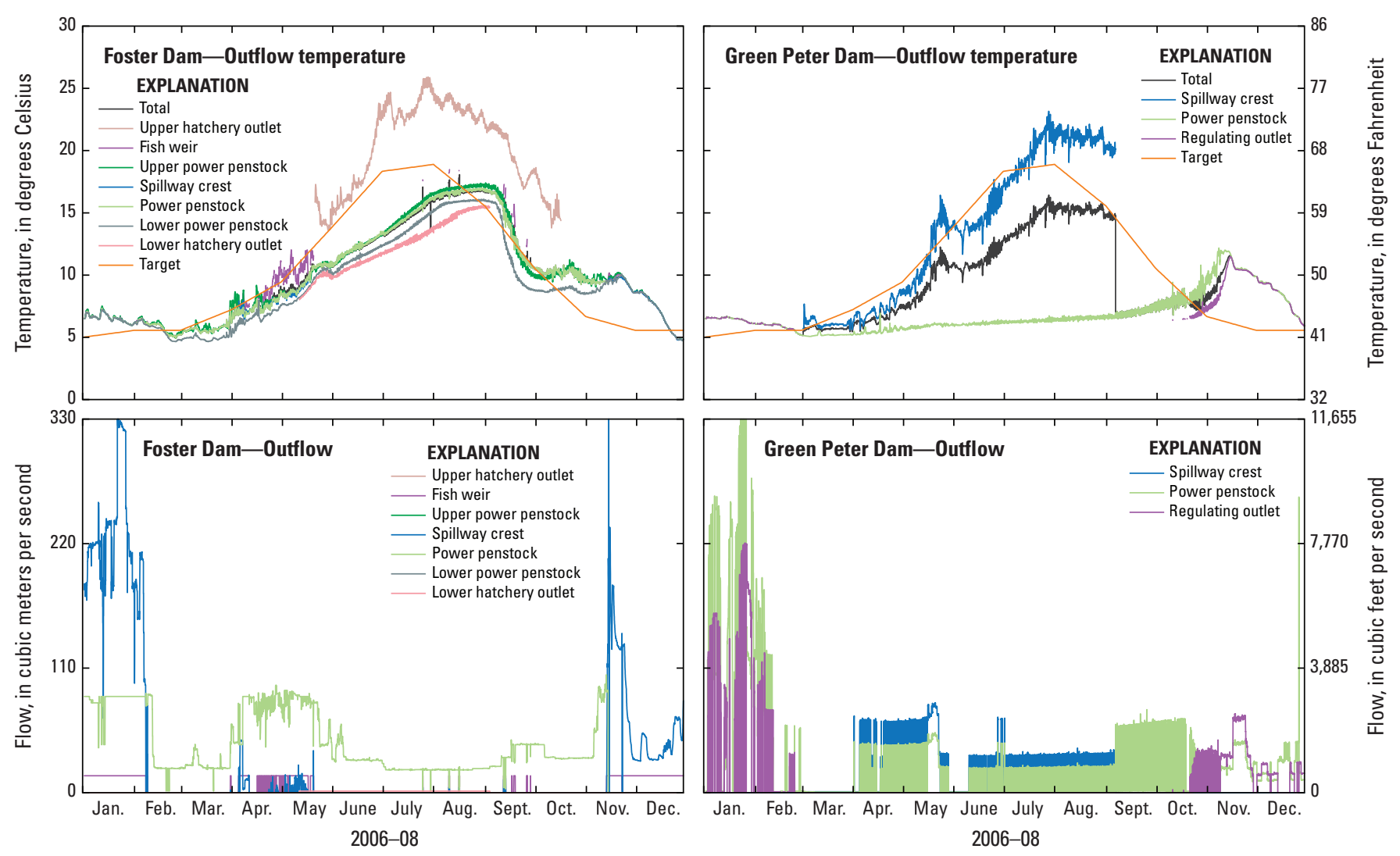

Figure 7. Flow and water temperature results for 2006-08 from Scenario 4, which specified a "natural" seasonal temperature target from Buccola (2017) for Green Peter Dam releases, and the minimum 40 percent power penstock flow at Green Peter and Foster Dams, Oregon. The model year 2006-08 is a hybrid that combined portions of 2006 and 2008 to achieve hydrologically normal conditions. Hatchery flow was 1.4 cubic meters per second $(\mathrm{m} 3 / \mathrm{s})$ from May 11 to September 3.

\section{Scenario 5 Natural Step Temperature Target}

Scenario 5 used a modification of the Buccola (2017) temperature target and tested several possible water-management strategies at Green Peter Dam. The constraints of Scenario 5a did not allow the use of the spillway; therefore, cold, deep water was discharged from the lower outlets during summer, with relatively warm surface waters released in autumn and early winter as Green Peter Lake was drawn down in preparation for flood-risk management operations (fig. 8). In Scenario $5 \mathrm{~b}$, allowing use of the spillway at Green Peter Dam resulted in the release of warm surface waters through September, and the discharged waters approached the seasonal step temperature target until the lake level was drawn down and access to the spillway was lost. Releasing relatively more warm water from the lake surface in summer also meant that the autumn and early winter releases were not quite as warm as in Scenario 5a and closer to the colder temperature targets in winter. Scenario $5 \mathrm{c}$ was similar to $5 \mathrm{~b}$, except that spillway releases were limited to 60 percent of the total release, and the resulting release temperatures were less warm during summer and not as cool in autumn-winter, relative to Scenario 5b. Scenario $5 \mathrm{~d}$ substituted the spillway for a floating outlet that could access warm surface waters of the lake all season, and achieved the closest match to the temperature target, though releases were still somewhat cooler than the target in spring. The floating outlet was able to track the lake water surface to maximize the use of warm surface waters. The floating nature of the outlet also meant that the outlet could continue to be used, even after the date when the use of the fixed elevation spillway outlet was lost in scenarios $5 \mathrm{~b}$ and $5 \mathrm{c}$.

Downstream in Foster Lake and at Foster Dam, the cold waters released from Green Peter Dam in Scenario 5a were warmed and mixed with inflows from the South Santiam River so that releases from Foster Dam had some semblance of a natural seasonal pattern but still were generally cooler than the temperature target in summer and warmer than the target in autumn (fig. 8; table 4). Scenarios $5 \mathrm{~b}$ through $5 \mathrm{~d}$ also showed changes and a possible time lag in water temperature between Green Peter and Foster Dams. For a period in late summer and autumn, the released temperatures at Foster Dam were slightly warmer than the target that was implemented at Green Peter Dam, which could have been due to some warming in Foster Lake, but more likely a manifestation of the travel time of water through Foster Lake and a resultant time lag in the temperature pattern. The release temperatures at both dams in spring remained cooler than the target, regardless of any warming that may have occurred in Foster Lake. 
Scenario 5a-No spill, 2011
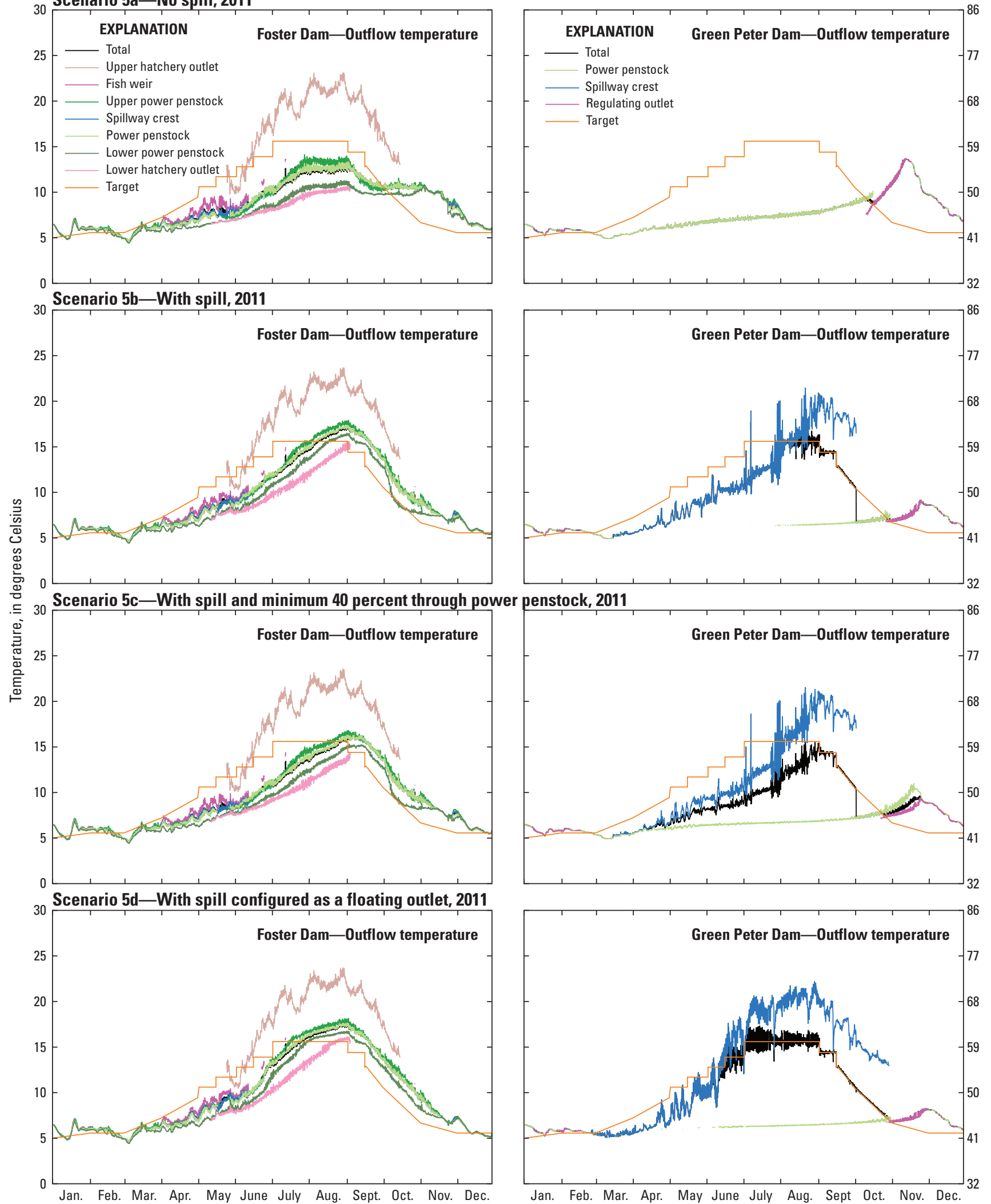

2011

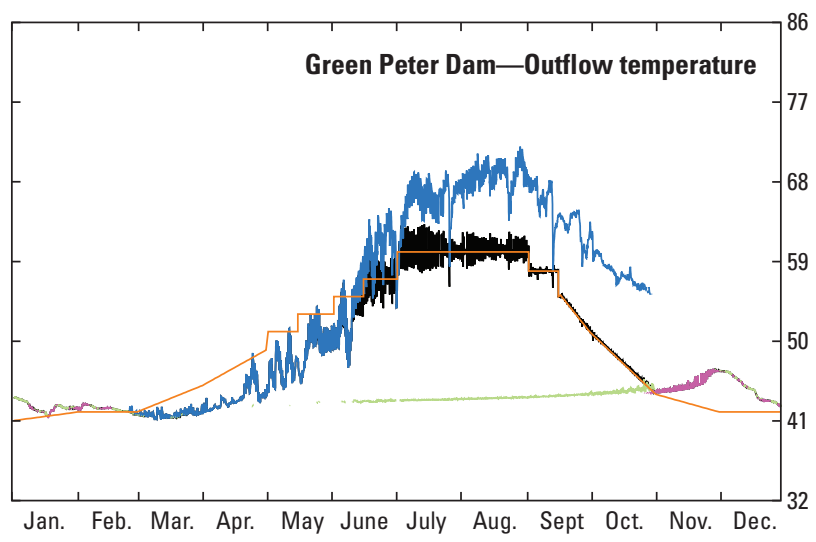

2011

Figure 8. Water temperature results for year 2011 for Scenario 5 for releases from Foster and Green Peter Dams, using a natural step temperature target and various outlet constraints for Green Peter Dam, Oregon. 
Water temperature profiles in Foster Lake just upstream from Foster Dam showed stratified conditions in summer and autumn with warmer surface waters and cooler bottom waters (fig. 9). The outlets at Foster Dam accessed these stratified waters such that the fish weir (the outlet at the highest elevation [5.7 $\mathrm{m}$ ] above the main power penstock intake; table 1), released warmer water than the power penstock (table 6). The Foster Dam spillway is only $2.1 \mathrm{~m}$ above the power penstock, so the release temperatures from the spillway and power penstock were more similar (table 7). The lower hatchery outflow was the lowest elevation outlet and also the coolest release at Foster Dam (table 8), though still warmer compared to base case conditions in most scenarios. Note that release temperatures are determined in the model not only by the elevation of the outlet and the temperature of the water in the lake near that outlet, but also by the flow through that outlet. Larger flows cause water to be drawn from a wider range of depths, taking into account the density (temperature) of water in different layers of the model next to the dam. Therefore, large flow releases from a higher-elevation outlet can conceivably draw water from a wider range of depths and result in a slightly cooler overall release temperature than small flow releases from a lower-elevation outlet. The effect is subtle, but accounts for some of the perhaps-unexpected temperature differences in table 7. Overall, higher outlets like the fish weir at Foster Dam typically were predicted to release warmer water during summer than releases through the lower-elevation power penstock, or the even-lower-elevation fish hatchery outlet.

\section{Downstream Effects in the South Santiam River}

Changing operations at Green Peter Dam in Scenario $5 \mathrm{c}$ resulted in a more natural seasonal temperature pattern released at Foster Dam, with warmer water temperatures released from mid-April through early October and cooler temperatures released in late autumn and early winter, as compared to the base case in all years modeled (for example, fig. 10, top). Those release water temperatures had little to no daily variation because daily temperature variations in Foster Lake were small.

As water released from Foster Dam traveled downstream in the South Santiam River, conditions were shallower and more turbulent as compared to the lake. Thus, the shallower river water was exposed to more environmental heat exchange across the water surface, per unit volume of water. Unregulated tributaries also entered the South Santiam River downstream of Foster Dam. Together, these factors caused a gradual decrease in the effect of any altered upstream dam operations as water moved farther downstream in the South Santiam River (figs. 10-12). At the mouth of the South Santiam River in model year 2002, the dry model year, the temperature difference between Scenarios 0 and $5 \mathrm{c}$ was less than $(<) 1^{\circ} \mathrm{C}$ through mid-June and after mid-September and $<2.5^{\circ} \mathrm{C}$ from mid-June through mid-September. The altered dam operations at Green Peter Dam in Scenario 5c still had a measurable effect as far downstream as the mouth of the South Santiam River. However, environmental heat transfers across the river surface began to dominate the heat budget of the river and caused the river to "forget" its initial temperature when water was released from Foster Dam. The effect of altered operations at upstream dams would continue to diminish as the water travels farther downstream. 
Scenario 5a-No spill, 2011

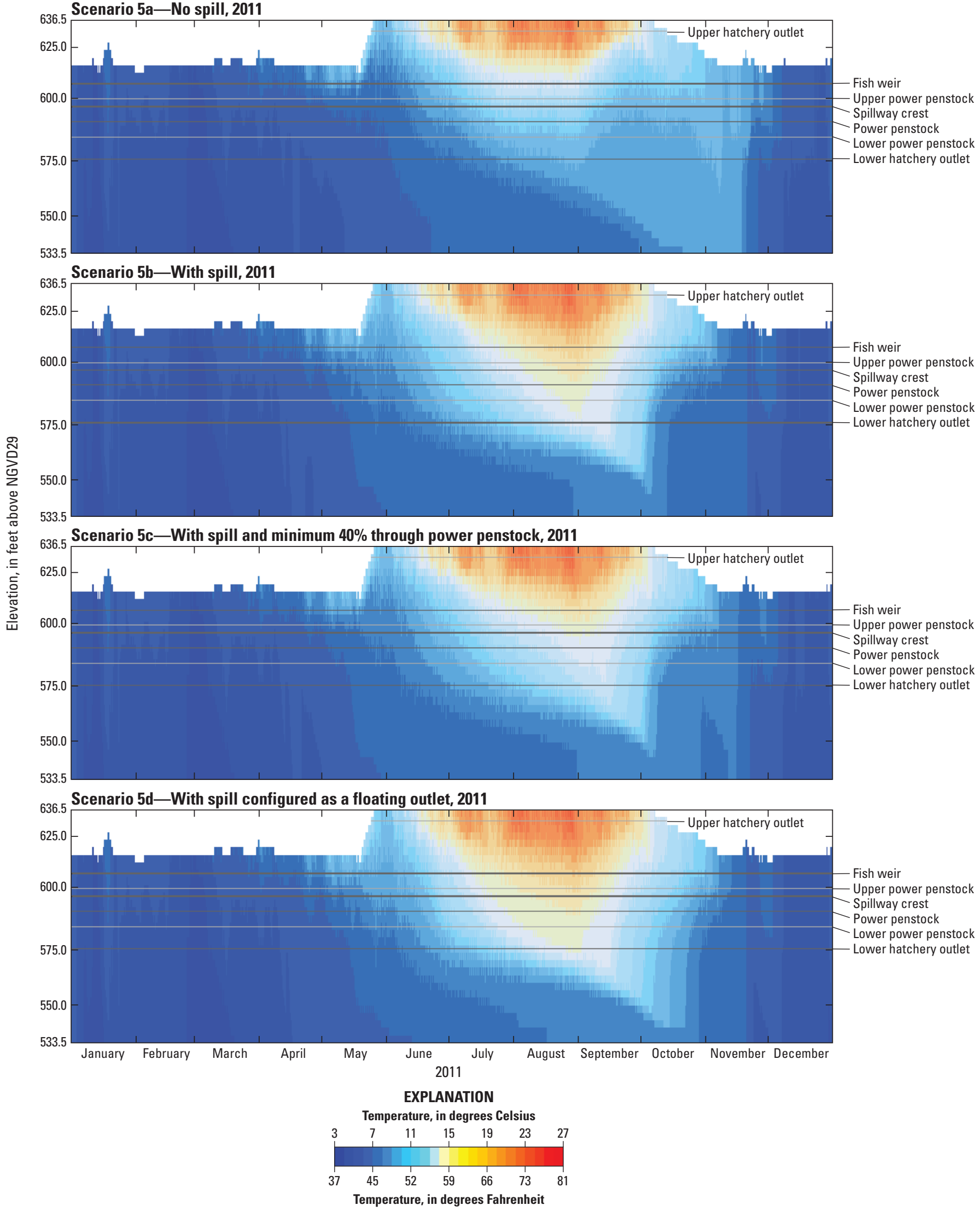

Figure 9. Modeled Foster Lake water temperature profiles just upstream of Foster Lake Dam, Oregon, for Scenario 5. 


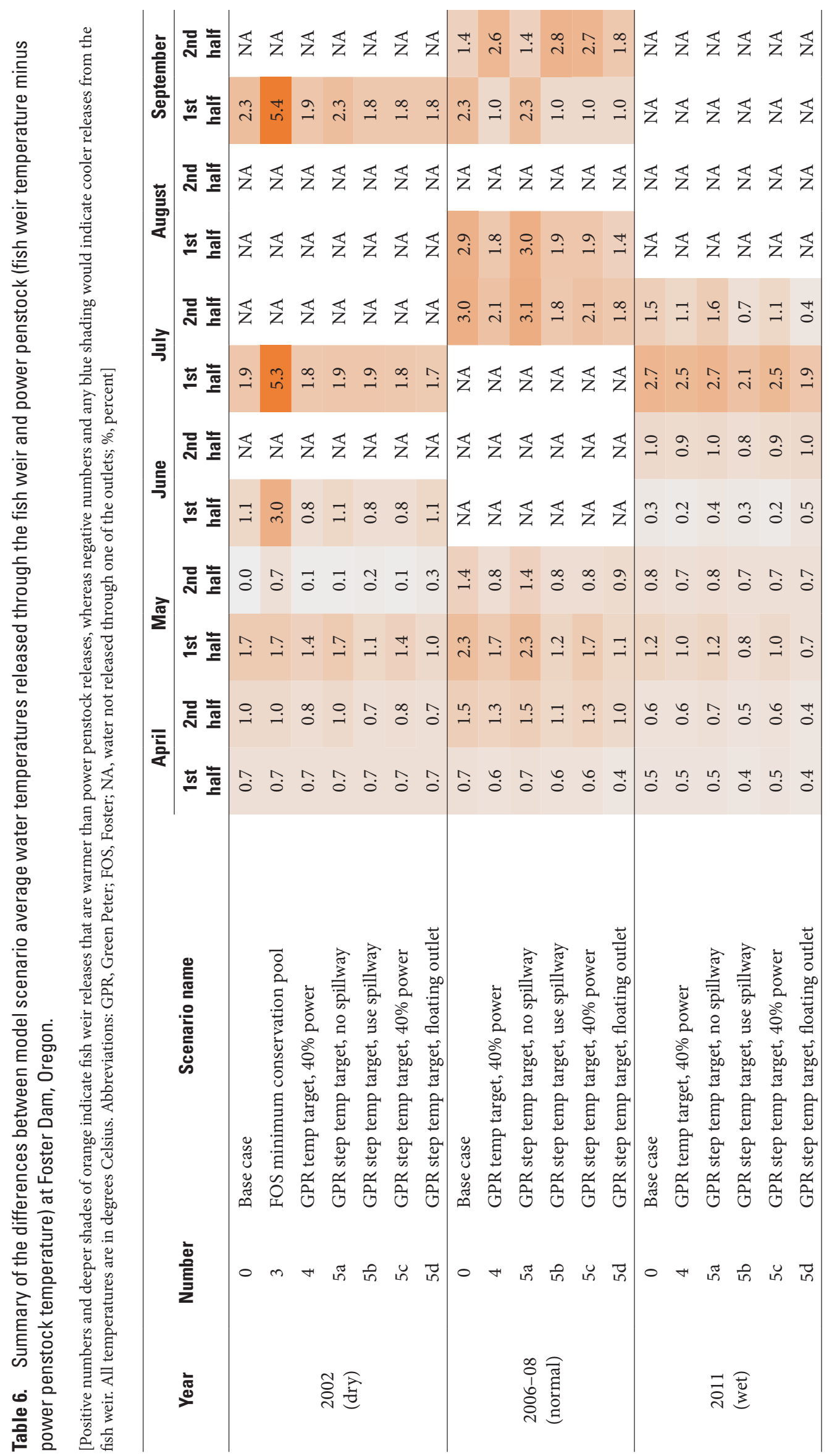




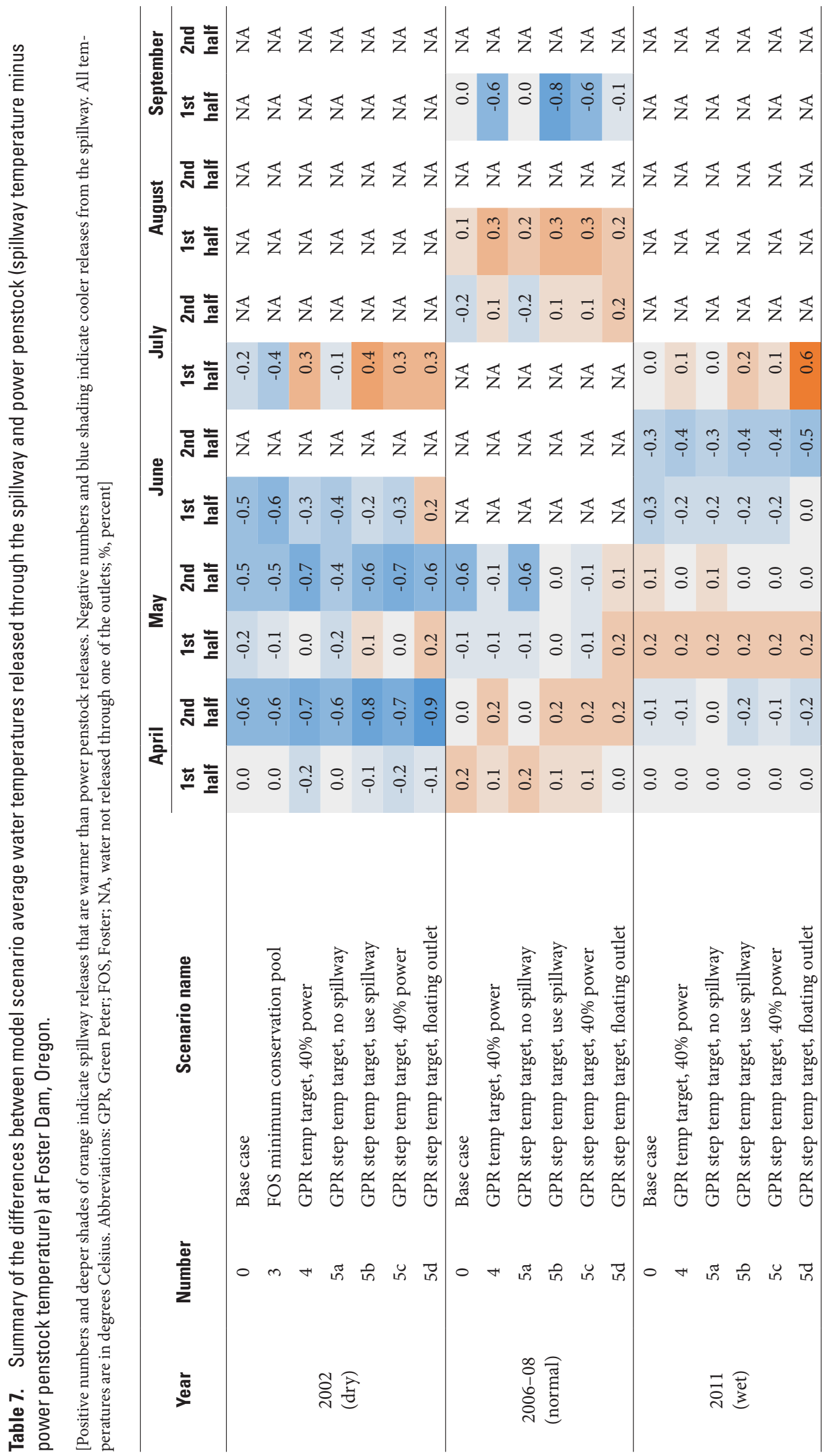




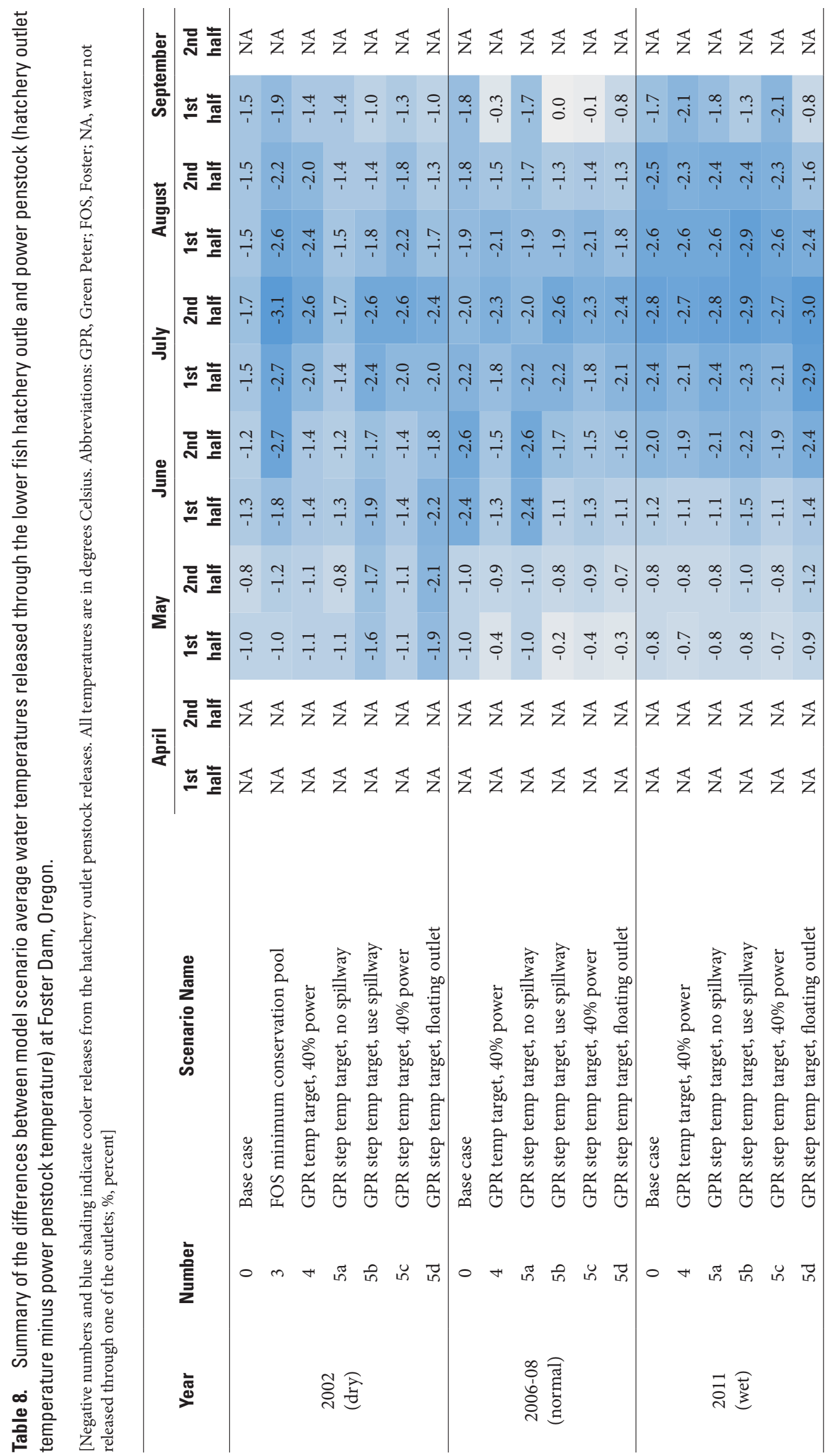



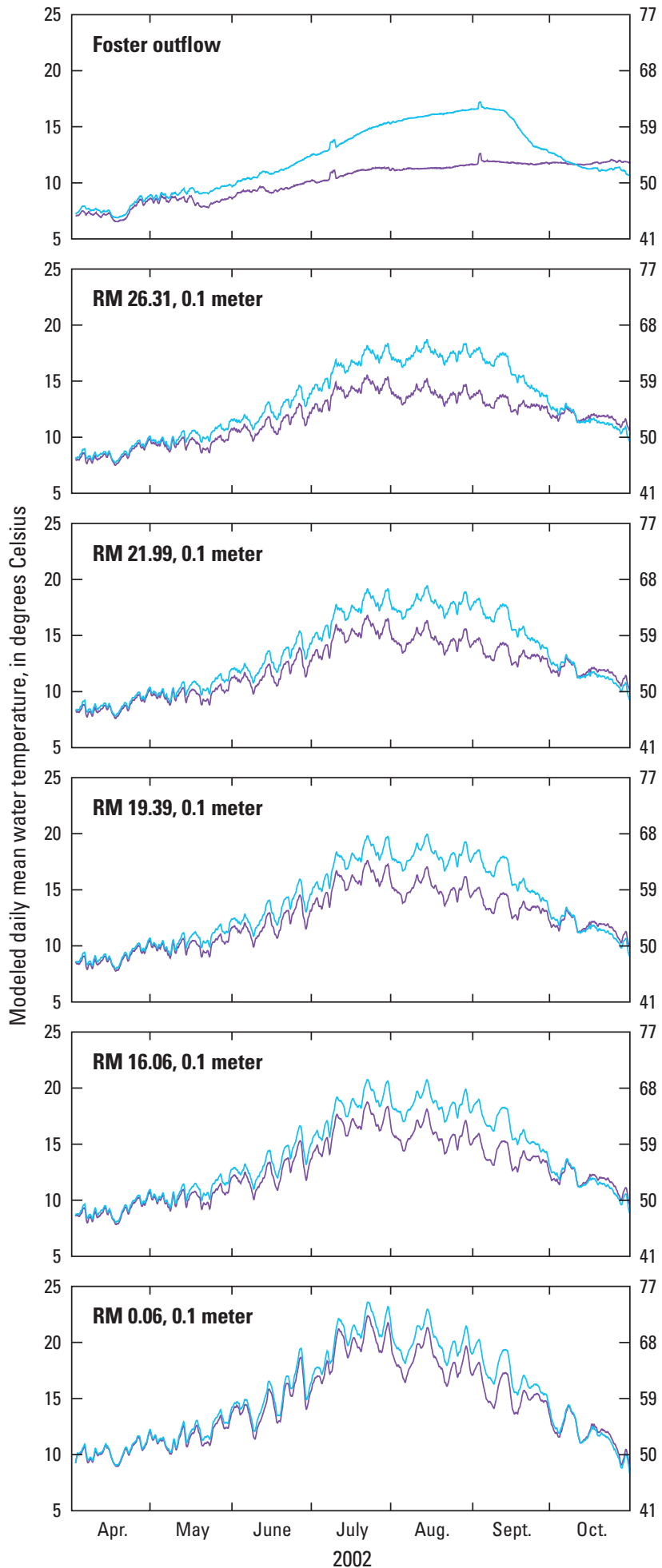

EXPLANATION

Base case $\quad$ Scenario $5 c$

Figure 10. Modeled daily mean water temperature at 0.1 meter depth in the South Santiam River, Oregon, at selected locations for the base case and Scenario 5c in 2002 [Abbreviation: RM, River Mile]. 


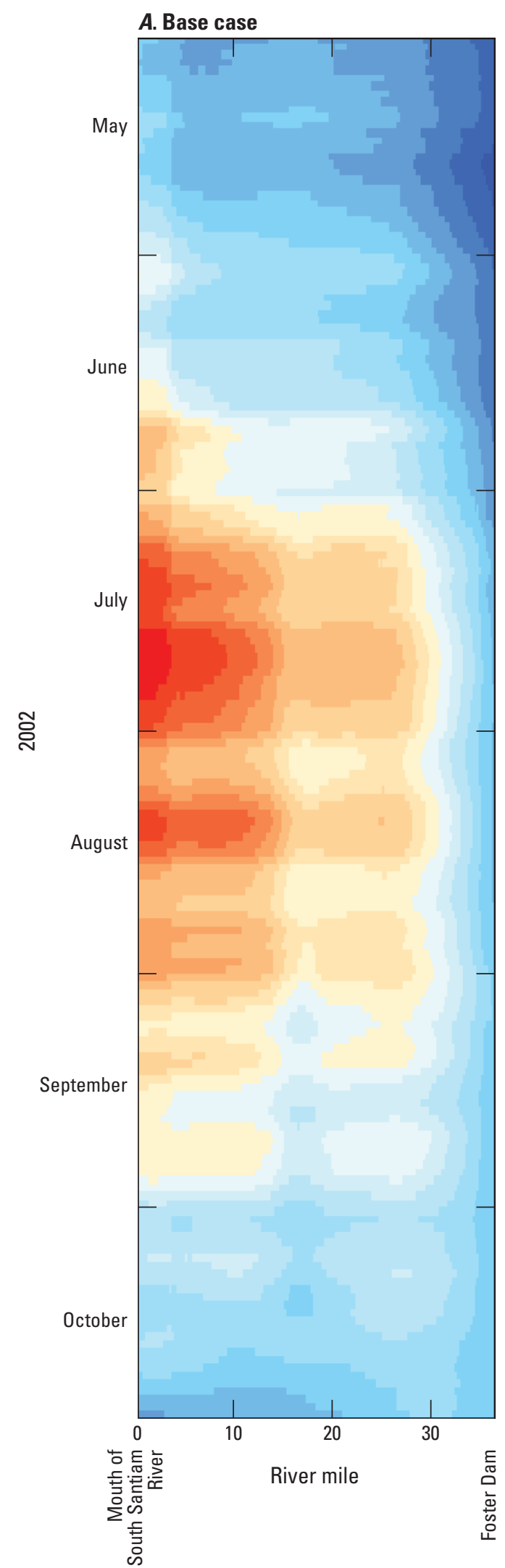

\section{B. Scenario 5c}

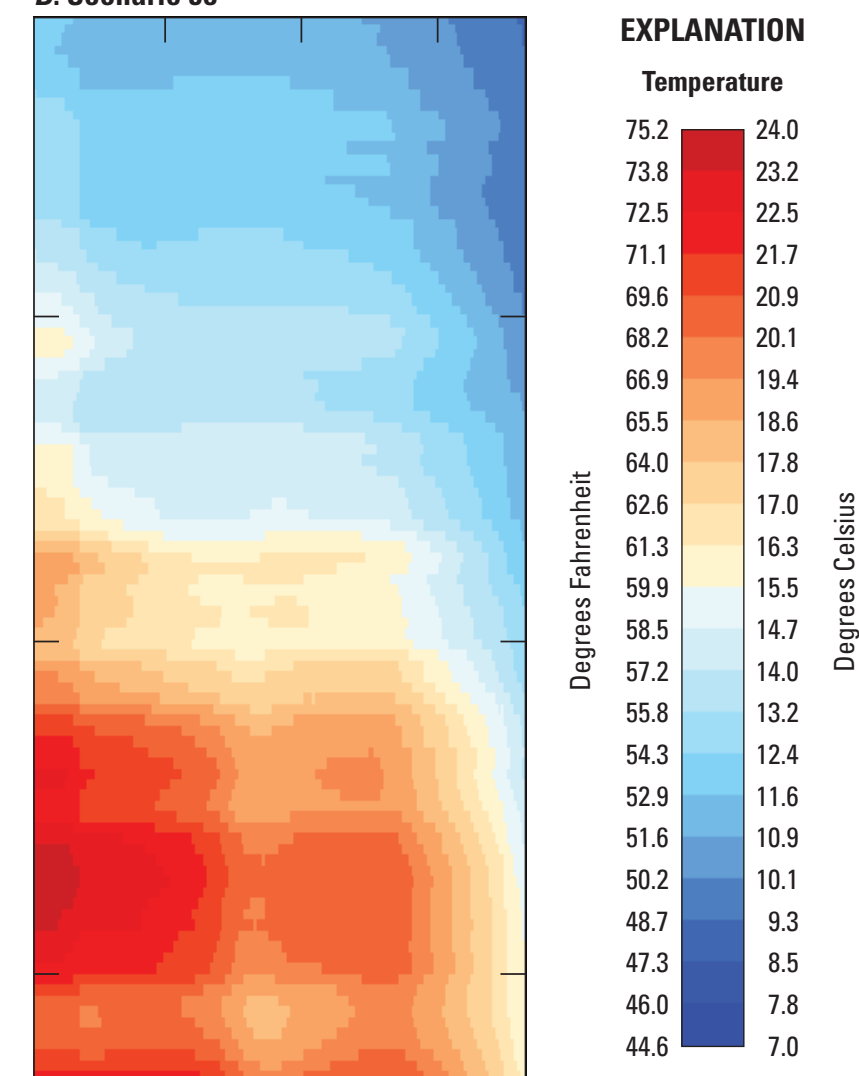

Figure 11. Modeled 7-day average of the daily maximum water temperature in the South Santiam River for the base case (A) and for Scenario 5c (B) during May-0ctober 2002. River mile 0 is at the mouth of the South Santiam River, Oregon. 


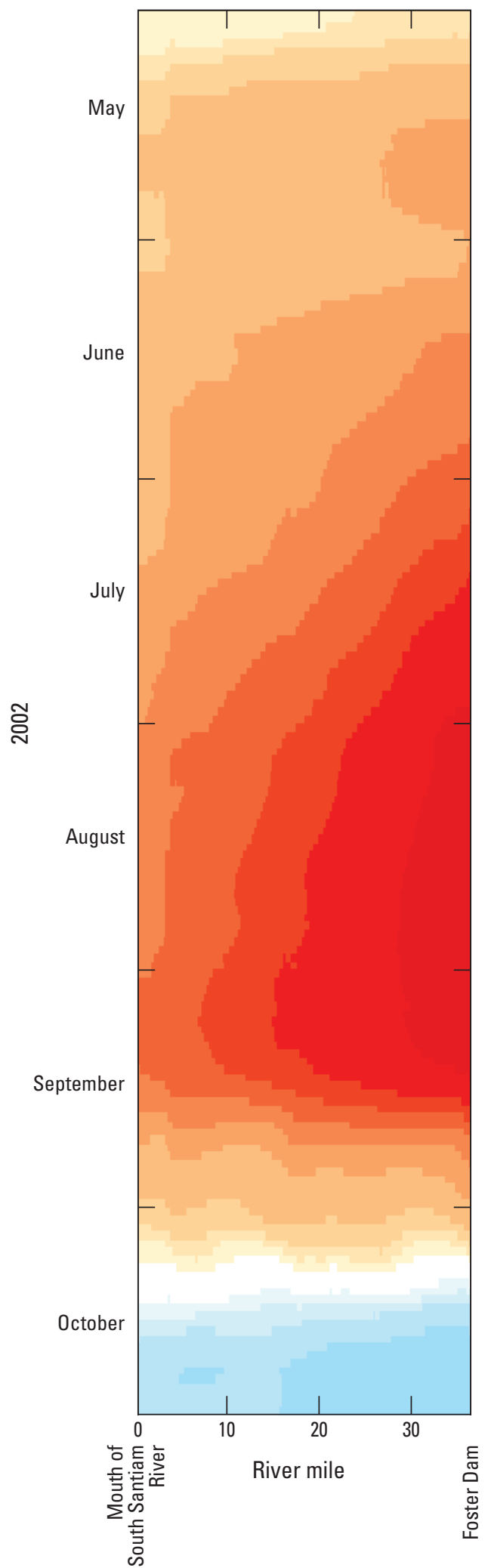

EXPLANATION

Temperature difference of the seven-day moving average of the daily maximum

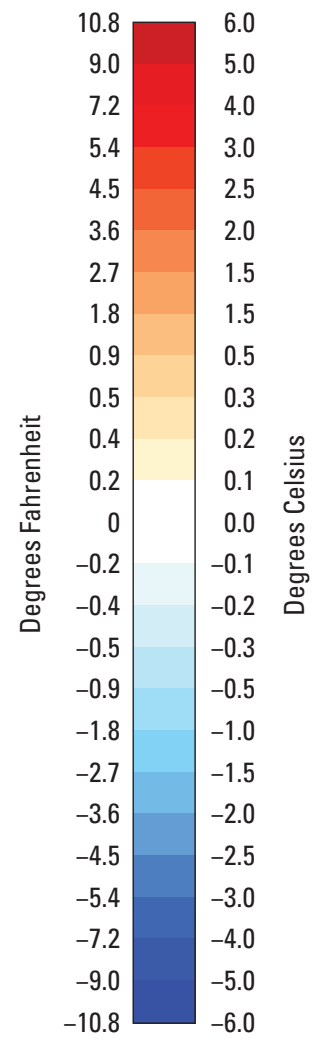

Figure 12. The difference in modeled 7-day daily average of daily maximum water temperature between Scenario 5c and the base case in the South Santiam River, Oregon, 2002. Positive differences indicate that modeled temperatures in Scenario $5 c$ were warmer than in the base case, whereas negative differences indicate that Scenario $5 c$ temperatures were cooler. 


\section{Implications for Monitoring and Management}

The operations of Green Peter and Foster Dams together had a substantial effect on water temperature in the Foster Dam fish ladder and downstream in the South Santiam River, such that managed water temperatures could mimic aspects of a more-natural seasonal pattern. Green Peter Dam operations effected larger temperature changes than operations at Foster Dam because Green Peter Dam impounds a large and deep lake, and the outlets at Green Peter Dam can draw from both warm surface waters and cold bottom waters during stratified periods.

Model simulations showed that significant temperature increases in Green Peter Dam outflow temperatures in summer were possible with releases of warm surface water from the spillway or from a hypothetical floating outlet, even as some releases were reserved for power generation. However, the effects of Green Peter Dam releases on water temperature were muted and delayed as the water traveled through Foster Lake and mixed with tributary South Santiam waters, making precise temperature control at the Foster Dam fish ladder using only operational changes at Green Peter difficult. Also, the ability to use the spillway was limited by annual hydrologic conditions. In the modeled years, the spillway was available to release water through early September (in 2002 and 2006-08) or late September (2011). In more extreme hydrologic conditions, the spillway may be available for different periods of time.

Operational changes at Foster Dam resulted in more immediate temperature changes at its fish ladder. However, the smaller range of stratified temperatures in Foster Lake and the relatively closer vertical proximity of the release outlets at Foster Dam made for smaller water temperature changes from Foster Dam operations. As Foster Dam fish ladder water temperatures are optimized through Green Peter or Foster Dam operations, the effects on the fish hatchery outlet water temperature may be relevant to management decisions..

Model scenarios such as those documented in this report can help managers formulate general operational recommendations as part of strategies to meet downstream temperature targets and (or) other water-management objectives. In tandem with insights gained from modeling, the continued measurement and telemetry of water temperature conditions downstream of Green Peter and Foster Dams will provide immediate feedback regarding the effectiveness of different operational strategies for controlling water temperature and optimizing conditions for sensitive aquatic species.

\section{Acknowledgments}

The authors thank several people and organizations for their assistance with this study. Chris Caudill and Matthew Keefer (University of Idaho) provided the block operations plans used for Scenario 2. Discussions with Norman Buccola, Ida Royer, Fenton Khan, Jacob Macdonald, and Richard Piaskowski (U.S. Army Corps of Engineers) and Laurel Stratton (U.S. Geological Survey) were helpful during model development and analysis.

\section{References Cited}

Bloom, J.R., 2016, South Santiam River, OregonHydrodynamics and water temperature modeling, 2000-2002: Portland, Oregon, Oregon Department of Environmental Quality, $53 \mathrm{p}$.

Buccola, N.L., 2017, Water temperature effects from simulated changes to dam operations and structures in the Middle and South Santiam Rivers, Oregon: U.S. Geological Survey Open-File Report 2017-1063, 19 p. [Also available at https://doi.org/10.3133/ofr20171063.]

Buccola, N.L., Stonewall, A.J., and Sullivan, A.B., Kim, Yoonhee, and Rounds, S.A., 2013, Development of CEQUAL-W2 models for the Middle Fork Willamette and South Santiam Rivers, Oregon: U.S. Geological Survey Open-File Report 2013-1196, 55 p. [Also available at https://pubs.usgs.gov/of/2013/1186/.]

Cole, T.M., and Wells, S.A., 2015, CE-QUAL-W2-A twodimensional, laterally averaged, hydrodynamic and waterquality model, version 3.72: Portland, Oregon, Portland State University, Department of Civil and Environmental Engineering, variously paged.

Cole, T.M., and Wells, S.A., 2017, CE-QUAL-W2-A twodimensional, laterally averaged, hydrodynamic and water-quality model, version 4.1 : Portland, Portland State University, Department of Civil and Environmental Engineering. [variously paged].

E\&S Environmental Chemistry, Inc., and South Santiam Watershed Council, 2000, South Santiam watershed assessment: E\&S Environmental Chemistry, Inc., and South Santiam Watershed Council, Final Report, 224 p. 
Fischer, H.B., List, E.J., Koh, R.C.Y., Imberger, J., and Brooks, N.H., 1979, Mixing in inland and coastal waters: Orlando, Florida, Academic Press, Inc., 483 p.

Keefer, M.L., Clabough, T.S., Jepson, M.A., Blubaugh, T., Brink, G., Naughton, G.P., and Caudill, C.C., 2018, Evaluation of adult chinook salmon behavior at the Foster Dam adult fish facility and in Foster Dam reservoir on the South Santiam River, 2017: Moscow, University of Idaho, Department of Fish and Wildlife Sciences, Technical Report 2018-3-Final, 87 p.

Moore, A.M., 1964, Compilation of water-temperature data for Oregon streams: U.S. Geological Survey OpenFile Report 64-115, 134 p. +1 pl. [Also available at https://pubs.er.usgs.gov/publication/ofr64115.]
Rounds, S.A., 2007, Temperature effects of point sources, riparian shading, and dam operations on the Willamette River, Oregon: U.S. Geological Survey Scientific Investigations Report 2007-5185, 34 p. [Also available at https://doi.org/ $10.3133 /$ sir20075185.]

Rounds, S.A., 2010, Thermal effects of dams in the Willamette River Basin, Oregon: U.S. Geological Survey Scientific Investigations Report 2010-5153, 64 p. [Available at https://pubs.usgs.gov/sir/2010/5153/.]

Rounds, S.A., and Buccola, N.L., 2015, Improved algorithms in the CE-QUAL-W2 water-quality model for blending dam releases to meet downstream water-temperature targets: U.S. Geological Survey Open-File Report 2015-1027, 36 p. [Available at https://dx.doi.org/10.3133/ofr20151027.]

West Consultants, Inc., 2005, Development of a CE-QUALW2 model for Green Peter and Foster reservoirs: Seattle, Washington, prepared for U.S. Army Corps of Engineers under contract DACW57-02-D-0005, 43 p. 

Publishing support provided by the U.S. Geological Survey Science Publishing Network, Tacoma Publishing Service Center

For more information concerning the research in this report, contact the Director, Oregon Water Science Center

U.S. Geological Survey

2130 SW 5th Avenue

Portland, Oregon 97201

https://www.usgs.gov/centers/or-water 
